Finance and Economics Discussion Series

Divisions of Research \& Statistics and Monetary Affairs

Federal Reserve Board, Washington, D.C.

\title{
Are Longer Bankruptcies Really More Costly?
}

\section{Daniel M. Covitz, Song Han, and Beth Anne Wilson}

2006-27

NOTE: Staff working papers in the Finance and Economics Discussion Series (FEDS) are preliminary materials circulated to stimulate discussion and critical comment. The analysis and conclusions set forth are those of the authors and do not indicate concurrence by other members of the research staff or the Board of Governors.

References in publications to the Finance and Economics Discussion Series (other than acknowledgement) should be cleared with the author(s) to protect the tentative character of these papers. 


\title{
Are Longer Bankruptcies Really More Costly?
}

\author{
Daniel M. Covitz \\ Song Han* \\ Beth Anne Wilson \\ Board of Governors of the Federal Reserve System \\ $20^{\text {th }}$ and C Streets NW, Washington D. C. 20551
}

June 2006

Please do not quote without permission.

\begin{abstract}
We test the widely held assumption that longer restructurings are more costly. In contrast to earlier studies, we use instrumental variables to control for the endogeneity of restructuring time and creditor return. Instrumenting proves critical to our finding that creditor recovery rates increase with duration for roughly $1 \frac{1}{2}$ years following default, but decrease thereafter. This, and similar results using the likelihood of reentering bankruptcy, suggest that there may be an optimal time in default. Moreover, the default duration of almost half of our sample is well outside the optimal default duration implied by our estimates. We also find that creditors benefit from more experienced judges and from oversight by only one judge. The results have implications for the reform and design of bankruptcy systems.
\end{abstract}

JEL Classification: G12, G14, G33, G34

*Corresponding author: Song Han (Song.Han@frb.gov). We would like to thank David Smith and Geoffrey Keim for their sizable contributions to this paper. We also benefited from the comments of Theodore M. Barnhill, Mark Carey, Michael J. Kelly, Michelle Rhyu, Jesse Weiher, Jonathan Wright, Hong Yan, and participants of seminars at the Federal Reserve Board and the University of Minnesota, the $16^{\text {th }}$ Derivative Securities and Risk Management Conference at FDIC, and the 2006 WAFA Conference, and from the research assistance of Dan Rawner. The views of this paper are solely the responsibility of the authors and should not be interpreted as reflecting the views of the Board of Governors of the Federal Reserve System or of any other person associated with the Federal Reserve System. 


\title{
Are Longer Bankruptcies Really More Costly?
}

June 2006

\begin{abstract}
We test the widely held assumption that longer restructurings are more costly. In contrast to earlier studies, we use instrumental variables to control for the endogeneity of restructuring time and creditor return. Instrumenting proves critical to our finding that creditor recovery rates increase with duration for roughly $1 \frac{1}{2}$ years following default, but decrease thereafter. This, and similar results using the likelihood of reentering bankruptcy, suggest that there may be an optimal time in default. Moreover, the default duration of almost half of our sample is well outside the optimal default duration implied by our estimates. We also find that creditors benefit from more experienced judges and from oversight by only one judge. The results have implications for the reform and design of bankruptcy systems.
\end{abstract}

JEL Classification: G12, G14, G33, G34 


\section{Introduction}

It is widely believed that financially distressed firms should be restructured as quickly as possible. In criticizing the U.S. bankruptcy system, Jensen (1991) writes that it "often takes years to resolve individual cases. As a result of such delays, much of the operating value of businesses can be destroyed."1 Based on this belief, restructuring practitioners - be they creditor representatives, bankruptcy judges or "turnaround" specialists - appear increasingly driven to speed up financial restructurings. ${ }^{2}$ Moreover, the recently enacted bankruptcy reform legislation, the Bankruptcy Abuse Prevention and Consumer Protection Act of 2005 (BAPCPA), has a number of elements specifically designed to expedite the bankruptcy process. ${ }^{3}$

Theoretically, however, it is not clear that faster is always better. The conventional wisdom is supported by the fact that the direct costs of restructuring - such as fees for retaining investment bankers, attorneys and restructuring professionals - increase with time, as well as by the belief that shorter workouts can lower the indirect costs of bankruptcy by limiting its impact on firm reputation, freeing-up valuable management time from drawn-out negotiations, and

\footnotetext{
${ }^{1}$ Restructuring speed is also considered important for resolving sovereign defaults. Krueger (2002) identifies speed as a key reason for developing a unified sovereign debt restructuring mechanism (SDRM): "The objective of an SDRM is to facilitate the orderly, predictable, and rapid restructuring of unsustainable foreign debt." Echoing Krueger in the context of collective action clauses for sovereign debt, the 2002 G-10 Working Group on Contractual Clauses states, "There is now broad agreement in the international community that having effective procedures to resolve sovereign debt crises expeditiously is in the interest of debtors and creditors."

${ }^{2}$ See, for example, LoPucki and Kalin (2001) and Ayotte and Skeel (2002). An example of practitioner emphasis on speed comes from the bankruptcy case of the retailer K-mart. K-mart's creditors arranged for the company's newly-appointed CEO, Jim Adamson, to be paid a $\$ 4$ million bonus if K-mart emerged from bankruptcy within 18 months of filing. The bonus was structured to decline after the 18-month deadline at a daily rate of $\$ 7,299$. Kmart emerged in May, 2003, two months before the deadline. See Yue (2002) and Skeel (2003).

${ }^{3}$ Specifically, the BAPCPA caps a debtor's exclusivity period to file a reorganization plan at 18 months after the commencement of the bankruptcy case and its exclusivity period to solicit votes on the plan at 20 months after the filing of a plan $(\$ 411)$. In contrast, the former bankruptcy code allows the court to extend both exclusivity periods indefinitely so long as the requisite cause is established. These new absolute deadlines may encourage more rapid plan proposals by debtors and thus lead to shorter proceedings as debtors try to minimize the ability of creditors to stall so as to cause the loss of exclusivity. Other amendments of the BAPCPA that may also expedite bankruptcy proceedings include a requirement for the debtor to make faster decisions on unexpired leases (\$404), and an absolute plan-filing deadline for small business cases (§437).
} 
reducing the extent to which firms forego valuable investment opportunities. ${ }^{4}$ However, academics have argued that bankruptcy may allow firms to refocus in a more profitable direction (e.g., Diamond (1993), Jensen (1993), Hart and Moore (1995), and Smith and Strömberg (2004)). Such restructurings may take time, creating a marginal benefit to spending more time in default. When these marginal benefits exceed the marginal costs of restructuring, creditor return may actually increase with time in default.

Empirically, existing studies evaluating the net costs of bankruptcy duration find mixed results. Consistent with the conventional view that speedier restructurings are preferred, Acharya, Bharath, and Srinivasan (2004) find a statistically significant, negative relationship between bond recovery rates and the time spent in default, and Thorburn (2000) finds that the costs of bankruptcy increase with the time in default. However, Andrade and Kaplan (1998) find that time spent in restructuring does not influence the costs of financial distress. In addition, Maksimovic and Phillips (1998) find a nonlinear impact of time spent in bankruptcy, with productivity declines observed only in those firms that exit immediately from bankruptcy and that are in bankruptcy for more than four years.

A potentially important limitation of the extant research in this area is its failure to address the possibility that time spent in default is endogenous. In general, as argued in Jensen (1989) and Hart (2000), claimholders' strategies, thus the time spent in default, are endogenously affected by firm values and restructuring costs. For example, defaulted firms with relatively high values - that is, those cases in which the firms are temporarily liquidity constrained, but

\footnotetext{
${ }^{4}$ Existing studies largely agree that the direct costs of bankruptcy are a small fraction of pre-default firm values (see, e.g., Altman (1984), Betker (1997), Bris, Welch, and Zhu (2004), LoPucki and Doherty (2004), Warner (1977), and Weiss (1990)). However, while some studies find the indirect costs are significant (e.g., Altman (1984), Andrade and Kaplan (1998), Gilson (1997), Hotchkiss (1995), and Opler and Titman (1994)), others argue for the opposite (e.g., Diamond (1993), Haugen and Senbet (1978), and Maksimovic and Phillips (1998)).
} 
otherwise close to solvency - may proceed quickly through a workout as creditors simply renegotiate their payment schedules. Such strategy would induce a negative correlation between the time spent in default and bond recovery rates, even if time had no causal effect on restructuring costs. Alternatively, creditors of low-value firms may "throw in the towel" if they anticipate only little recovery value to compensate for a lengthy fight, creating a positive correlation between the default duration and bond recovery rates. With endogenous time in default, simply regressing on the time spent in default yields biased estimates of the impact of time on recovery.

In this paper, we study the impact of firms' time in default on creditor return while explicitly addressing the issue of endogenous time in default. We conduct our analysis on a comprehensive dataset of about 1000 U.S. firms that defaulted on their publicly issued bonds and filed for bankruptcy between 1983 and 2002. We capture creditor return with bond recovery rates, measured at the resolution of the bankruptcy cases, and the likelihood of a firm reentering bankruptcy, or so called "Chapter 22" filings.

We use an instrumental variable (IV) approach to address the above endogeneity problem. In our analysis, we construct two IVs that are correlated with time in default but not directly correlated with the creditor return. Our first IV is the percentage of days during a firm's default period in which there were severe weather events such as blizzards or floods affecting the court where the firm filed for bankruptcy. Intuitively, inclement weather, while completely exogenous to the change of firm value, slows down the bankruptcy process if it leads to court closures or transportation delays. These delays could be substantial, both because the inclement weather events chosen are severe (e.g., hurricanes and blizzards) and so may have lingering effects, and because the rescheduling of court appearances requires the coordination of multiple 
parties. Importantly, the inclement weather variable has both time series and cross-sectional variation, as the events occur over specific days in specific regions of the country.

Our second IV is the real per-page fee of obtaining court documents such as bankruptcy dockets. Such fees serve as a proxy for the marginal productivity of the court processing technology. Higher processing productivity improves case management, for example, through more efficient document management, information transmission, and case scheduling. Thus, regardless of firm value, it would reduce the case processing time. This second IV has time series but no cross-sectional variation, since fees do not vary across courts.

Our results provide new evidence of a nonlinear relationship between the time firms spend restructuring and firm value. We find that, in contrast to the conventional wisdom and the earlier literature, bond recovery rates increase with time in default for roughly the first $1 \frac{1}{2}$ years after default, and only after that time, do they start to decrease. In the same spirit, we find that the likelihood of a firm reentering bankruptcy initially decreases with time in default for roughly the first $2 \frac{1}{2}$ years but then increases with time after that threshold. Taken together, these results suggest that time spent in default enhances firm values initially, but that bankruptcy protection becomes detrimental to firm values if the process extends too long. Thus, there appears to be an optimal duration for a bankrupt firm to work out a plan to maximize its value under bankruptcy protection. We calculate that roughly 50 percent of our sample has default duration outside of a two standard deviation band around the optimal duration, suggesting many firms are well away from their optimal default length. Finally, we also show that OLS regressions that fail to control for the endogeneity of time in default may misleadingly validate the conventional view that shorter bankruptcies are always preferable to longer ones. 
Although our analysis focuses on TID, we also study the impact of other features of the bankruptcy process. In particular, we examine the role of bankruptcy judges in shaping the value of a defaulted firm by looking at the effect of judge experience (represented by a judge's tenure) and the presence of multiple judges on a case. Surprisingly, neither variable has any impact on bankruptcy duration. However, both variables are found to have significant effects on creditor recovery rates. In particular, we find that creditor recovery rates increase with more experienced judges; we also find that having multiple judges oversee the case, either sequentially or simultaneously, destroys firm value and increases the likelihood of a firm reentering bankruptcy. Finally, we find that industry and macroeconomic conditions matter for both bond recovery rates and the likelihood of reentering bankruptcy.

The rest of this paper proceeds as follows. Section II lays out our empirical approach, section III describes the data and the definitions of key variables, and section IV presents our results. Section V concludes and touches on the implications of our results for the design of bankruptcy systems in both U.S. and international contexts.

\section{Empirical Approach}

We are interested primarily in the impact of TID on bond recovery rates. That is, we would like to estimate the following equation:

$$
\mathrm{REC}=\alpha+\beta X+\gamma \mathrm{TID}+\varepsilon,
$$

where the dependent variable, REC, is a measure of bond recovery rate (more on its definition later) and the independent variables are time in default, TID, and a set of control variables, $X$. As described below, $X$ includes bond characteristics, firm, industry, and macroeconomic variables, 
proxies for bankruptcy complexity, and bankruptcy process variables. The coefficient of interest is $\gamma$, which measures the impact of TID on recovery rate.

An OLS regression of (1) will produce a biased estimate for $\gamma$ when TID is endogenous. We use an IV approach to solve this endogeneity issue. Specifically, we assume that TID links to our IVs (details on this later) in the reduced-form according to

$$
\ln \mathrm{TID}=a+b Z+c \mathrm{IV}+v,
$$

where the control variables, $Z$, include firm, industry, and macroeconomic variables, proxies for bankruptcy complexity, and bankruptcy process variables. Note that the dependent variable of (2) enters nonlinearly into our main equation (1). Thus, to estimate (1) and (2) jointly, we adopt the nonlinear limited information maximum likelihood methods (NLLIML) proposed by Amemiya $(1985, \S 8.1 .3)$ with a modification to account for censoring in TID, because some bankruptcy cases were pending at the time of our data collection.

Specifically, let $p=1$ if a bankruptcy case is pending and let $p=0$ otherwise. Let $s=t-t_{0}$ be the period from the time of default $t_{0}$ to the time of data collection $t$. Then TID $\geq s$ for the pending cases. Assume that $\varepsilon$ and $v$ follow a bivariate normal distribution with standard deviations $\sigma_{\epsilon}$ and $\sigma_{v}$ and correlation $\rho$. Denote their probability density function by $f(\varepsilon, v)$. Then the log-likelihood function is 5

$$
\ln f=\Sigma_{\mathrm{i}} p \ln \operatorname{Prob}(\mathrm{TID} \geq s)+(1-p) \ln f(\varepsilon, v)
$$

We use the Huber/White robust method to compute the standard errors of the estimated coefficients. Our IV approach implies that the parameter $\gamma$ in equation (1) is an unbiased

\footnotetext{
${ }^{5}$ By assuming a normal distribution for $v$, our maximum likelihood method estimates a censored lognormal survival model for TID. Li (1999) shows that both lognormal and log-logistic survival models fit well the TID data for junk bonds. Helwege (1999) used an OLS regression to fit the junk bond TID data. Bandopadhyaya (1991) used a Weibull survival model and Orbe, Ferreira and Nunez-Anton (2002) used a censored partial regression model to estimate time spent in Chapter 11 bankruptcy.
} 
estimator for the impact of exogenous shocks to TID on bond recovery rates. A negative $\gamma$ suggests that faster workouts increase recovery rates.

We also estimate several alternative specifications of equation (1). First, we add $\mathrm{TID}^{2}$ to the right-hand side of (1) to test whether the impact of TID on recovery rate is nonlinear. Second, we use $\log$ (TID) instead of TID to address the concern that the distribution of TID is skewed. Third, we test whether the effect of TID varies with certain firm characteristics or certain time periods. To do so, we augment equation (1) with interactions between TID and variables that proxy for the complexity of the restructuring (e.g., firm size, the number of creditors, and the likely involvement of unions in the creditor negotiations) and macroeconomic conditions at the time of the default. Finally, we estimate the impact of TID on the likelihood of a firm refiling for bankruptcy within five years after emerging from a previous bankruptcy case. Such likelihood is used in the literature as an alternative measure for the successfulness of a restructuring. We provide more details on this estimation in Section VI.4.

\section{Data and Definitions}

To evaluate the importance of time spent in default and other aspects of the bankruptcy process, we first construct a comprehensive sample of bonds from about 1000 firms that defaulted on their publicly issued bonds and filed for bankruptcy between 1983 and 2002 by combining Moody's Default Risk Service (DRS) Database and databases from S\&P's CreditPro and Portfolio Management Data (PMD). Below we detail the construction of the key variables in our analysis, including time in default (TID), bond recovery rate (REC), and potential determinants of recovery rates. Information on the data sources, variables definitions and their sample statistics is also summarized in Table 1. 


\section{Time in Default (TID)}

We measure TID as the number of months from a firm's first default event to its resolution of bankruptcy. A default occurs when the issuing firm misses interest or principal payments, files for bankruptcy or announces a distressed exchange. ${ }^{6}$ Not all defaulted firms file for bankruptcy. A firm can resolve the default through an out-of-court restructuring, such as simply curing the default, completing a distressed exchange, or liquidating. We restrict our sample to those firms that resolve default through the formal bankruptcy process, including filing for either traditional or prepackaged Chapter 11 reorganization, or for Chapter 7 liquidation. ${ }^{7}$ The outcome of a bankruptcy can be reorganization, liquidation, or merger and acquisition. We use a firm's first default event as the starting point, instead of the date of bankruptcy filing, because restructuring often begins when the firm defaults.

Data on the date of default are included in Moody's DRS and S\&P's CreditPro and PMD databases. These databases have limited information on the date of bankruptcy resolution, so we supplement them with the data from various news sources. Among the 1045 unique firm-default events, 37 were still in the bankruptcy process as of July 30, 2004 when the final data collection was done, 951 had resolved (of which 119 were liquidated), and the outcomes of the rest of the 61 firm-default events were not identified and were dropped from the sample.

\section{Recovery Rates on Defaulted Bonds}

We use recovery rates on defaulted bonds (REC) to capture variation in restructuring costs. REC is defined as the market value of the assets received by the bondholder, as a percent

\footnotetext{
${ }^{6}$ A distressed exchange occurs when bondholders exchange their bonds for new securities of lesser value, and it may fail if the firm cannot get sufficient bondholder approval.

${ }^{7}$ In a prepackaged Chapter 11 , the firm negotiates a reorganization plan with, and get approval from, its main creditors before filing with the bankruptcy court.
} 
of par value of the bond, when the firm resolves its bankruptcy. This recovery concept, measuring roughly the return to a bond holder who purchases the bond at par and holds it until the resolution of bankruptcy, has been frequently used in previous literature (e.g., Acharya, et al (2004) and Carey and Gordon (2004)). ${ }^{8}$ The primary data on recovery rate at resolution are from S\&P's CreditPro and PMD databases. We discount REC using the Merrill Lynch speculativegrade bond yield index at the time the firm defaults. Results are similar when discounting using short-term Treasury rates or when not discounting, and they are available upon request.

\section{$\underline{\text { 3. Explanatory Variables }}$}

\section{A. Firm, Industry, and Macroeconomic Variables}

In the regression equations for both TID and bond recovery rate, we include standard firm-level financial ratios constructed using information from firm balance sheets and income statements, industry-level financial ratios, and macroeconomic variables. Specifically, we consider the firm's book leverage ratio (i.e., total liabilities over total assets), asset tangibility (tangible assets over total assets), and return on assets (income before interest, taxes, depreciation and amortization over total assets). We include these firm-level financial ratios in the reduced-form regression of time in default (equation (2)) because, as we discussed above, time in default may be related to firm value. These variables are also included in the bond recovery rate equation because, ceteris paribus, stronger financials imply higher recovery rates.

\footnotetext{
${ }^{8}$ We also use two other measures, not shown, to capture the variations in restructuring costs: One is bond recovery rate at default, measured by bond price the end of the month of default, which data are from Moody's DRS; the other is the rate of return that an investor receives, above a benchmark market return, on a defaulted bond if the investor buys the bond at default and holds it until the resolution of bankruptcy. Our key results still hold for both measures.
} 
Firm value also depends on industry conditions. All else equal, favorable industry conditions could boost a firm's market value and induce a faster reorganization (Shleifer and Vishny (1992)). Therefore, we also consider industry leverage ratios and return on assets, as well as an industry market-to-book ratio - a standard measure of growth opportunity. Both firm and industry variables are obtained from Compustat. All industry variables are the median values for firms with the same 2-digit SIC codes. In addition, we include dummy variables for whether a firm is in the energy or utility industries and whether a firm is in the financial services industry. These dummies are used to control for industry specific effects on both time in default and recovery rate, as previous research suggests firms in these industries may behave differently from other firms because they are regulated (see Acharya et al. (2004), Covitz and Han (2005), and Varma and Cantor (2005)).

Firm value may be boosted by favorable macroeconomic conditions. ${ }^{9}$ We measure macroeconomic conditions with three standard asset price variables: a short term interest rate (3-month T-bill rate), the slope of the interest-rate term structure or "term premium" (the 10-year Treasury yield less the 3-month Treasury yield), and junk bond yields spreads (yield on speculative-grade corporate bonds estimated by Merrill Lynch less comparable maturity Treasury yield). Term structures are used to measure both current and expected economic strength and junk bond spreads proxy for risk premia. Data on the term structure are from the Federal Reserve Board's public website and junk bond spreads are from Bloomberg. In terms of timing, we use the data on these variables at the point of time as close as possible to the default.

\footnotetext{
${ }^{9}$ See, for example, Acharya, Bharath, and Srinivasan (2004), Altman, et al (2005), Carey and Gordon (2004), Covitz and Han (2004), and Varma and Cantor (2005) for some evidence of macroeconomic effects on bond recovery rates.
} 
Specifically, firm variables are for the end of the quarter immediately before the default, and industry and macroeconomic variables are for the end of the quarter of default.

Finally, in our TID and REC regressions we include changes in industry and macroeconomic conditions from the date of default to the resolution of bankruptcy. These variables may matter because, for example, the risk of failure of any business plan is higher, ceteris paribus, in an environment with deteriorating economic activity; thus a firm may find it harder to convince creditors on its reorganization plan. Therefore, a deterioration in aggregate economic conditions might induce a firm to spend more time under the protection of the bankruptcy code and may also dampen bond recovery rates.

\section{B. Bankruptcy Complexity Variables}

The degree of complexity of a bankruptcy case may affect both default duration and the bond recovery rate. Complex bankruptcies may take longer-potentially generating greater fees and causing more lost opportunities for the firm. On the other hand, more time may be especially necessary for complex cases in order to draw up a successful plan.

We construct four proxies for bankruptcy complexity. The first is the number of creditor classes which we approximate by the number of debt seniority classes, including senior secured, senior unsecured, senior subordinated, subordinated, junior subordinated, and bank loans. It is reasonable to assume that more classes make it more difficult to reach an agreement in the bargaining and negotiating process. The second variable is total assets (in real log-level dollars), a proxy for the size of the bankruptcy case. Larger firms presumably have a more complicated capital structure, more business lines, and a greater number of competing interests. Data on total assets are for the end of the quarter immediately before the default and are from Compustat. The 
third complexity variable is a dummy variable indicating whether a default is triggered mainly by "non-financial" reasons, including accounting fraud, product liability litigation, labor contract dispute, and environmental lawsuit. Excess litigations would lengthen the reorganization process and divert resources away from the distribution to bondholders. The data are collected from annual publications of the Bankruptcy Yearbook and Almanac. The information is crosschecked with and supplemented by the data using Lynn M. LoPucki's Bankruptcy Research Database (WebBRD). ${ }^{10}$ The fourth variable is the union membership of the firm's industry, a proxy for the union impact on the firm's reorganization. Data on the industry union membership are compiled by Hirsch and Macpherson (2003).

\section{Bankruptcy Process Variables}

The institutional aspects of the bankruptcy process may also be important for both time in default and firm value. In particular, it has been said that bankruptcy judges play an important role in restructuring outcomes (see, e.g., LoPucki and Kalin (2001) and LoPucki (2005)). We specifically examine the impact of judge tenure and the incidence of multiple judges during a bankruptcy proceeding on default duration and creditor recovery. We use the tenure of the judge at time of firm bankruptcy as a measure of judge experience. We construct a "multiple judge dummy variable" to indicate cases with more than one judge. This occurs if two or more judges oversaw a case simultaneously, as often happened in bankruptcies associated with asbestos litigation, or if a case was tried during the period when Delaware used visiting judges. It also occurred if more than one judge sequentially oversaw the bankruptcy either because the initial

\footnotetext{
${ }^{10}$ The WebBRD contains over 600 large cases of public companies that filed for bankruptcy since October 1980. The data are collected from bankruptcy court filings, SEC filings, and news stories. For details, see http://LoPucki.law.ucla.edu/index.htm.
} 
judge died or retired, the case was changed to a different venue, or the case was reassigned due to overcrowding in the Delaware docket. While the change in judge is independent of the case itself, it may cause disruption and delays that could impact the time spent in default. A reassignment of the judge may also affect the efficiency of the reorganization if the new judge's unfamiliarity with the case allows the firm management more discretion to act in its own interest at the expense of creditors. Twenty-five bonds from 16 firms in our regression sample have more than one judge.

\section{Instrumental Variables (IVs) for Time in Default}

To address the issue of endogeneity between firm value and time in default, we use two IVs for TID—variables that are correlated with TID but uncorrelated with bond value (except potentially through their impact on TID). ${ }^{11}$ Our first IV, "weather disruption," is constructed as the percentage of days during a firm's time in default in which the county of the firm's bankruptcy court was hit by severe weather or natural disasters. These weather conditions, while they may last only a short period of time, are so severe that they may cause lingering disrupting effects on normal working schedules. We normalized the number of bad weather days by total time in default to adjust for the fact that the longer the bankruptcy, the more likely it is to include incidents of inclement weather. The variations in this normalized variable measure the randomness of inclement weather; thus, to the extent that severe weather causes processing delays, this variable captures the exogenous cross-sectional variations in time in default.

The weather disruption variable is constructed from a variety of sources (see appendix for details). The Delaware and New York Southern District Courts provided dates when the courts

\footnotetext{
${ }^{11}$ We explore two other IVs for time in default: federal government shutdowns around the end of 1995 attributed to a standoff between House Majority Leader Newt Gingrich and President Bill Clinton, and unanticipated changes in the judge presiding over a bankruptcy case. However, these variables were not statistically significantly correlated with time in default and, thus, not valid IVs.
} 
were closed due to severe weather from 1994 to 2003 . We augment these with data on severe weather events from 1993 to the present from the Storm Events Database of the National Climatic Data Center (NCDC) of the National Oceanic and Atmospheric Administration (NOAA). Finally, we included seismic events for the Northern and Southern California courts. On average, firms experienced 3 days of inclement weather during bankruptcy, or 0.5 percent of the duration of default, in the period from 1993 to 2002.

Our second IV, "document fee," is the real per-page cost of access to court documents at the time of default. According to the Administrative Office of the United States Courts, the Courts set these fees to offset the costs incurred in providing technological services to facilitate access to court documents; thus the fees serve as a signal of the court's marginal cost of producing documents and can proxy for a court's ability to process bankruptcy cases efficiently. Greater court process efficiency, regardless of firm value, may translate into faster resolution of bankruptcies. Importantly, however, fees only capture the time series variation in efficiency, as they are the same for all 90 federal bankruptcy courts at a given time. Over our sample, document fees declined from 50 cents per page in 1983 to 7 cents per page (or 4 cents in 1983 dollars) in 2002. Data on historical document fees are from the Administrative Office of the United States Courts.

\section{Empirical Results}

This section presents our empirical analysis on the relationship between recovery rates and time in default. We begin by estimating the determinants of TID and demonstrating that our IVs are valid. We next show that it is critical to control for the endogeneity between default duration and creditor return. Initial regressions using OLS of recovery rates on TID find a 
significant negative coefficient on TID, seemly supporting the conventional wisdom that time is costly. However, once we control for endogeneity in TID, such coefficient becomes insignificant. In addition, our NLLIML estimations with nonlinear specifications reveal a complex relationship: TID enters positively and significantly while TID squared has a negative coefficient. The point estimates of these coefficients suggest that initially additional time in default benefits creditors but after a certain duration, net effect begins to turn negative. Finally, we test the robustness of this result, including whether TID has a similar effect on an alternative measure of restructuring costs -- the likelihood of a firm reentering bankruptcy.

\section{Analysis of TID}

Table 2 presents the results on the determinants of TID using a censored lognormal survival model. The duration variable is the firm-level TID. Focusing on our key specifications, the specification in column (3) includes industry, macroeconomic, and bankruptcy process variables as well as the real per-page document fee (our first IV) and the weather disruption variable (our second IV). The specification in column (6) augments that of (3) with firm-level financial variables. In all specifications in the paper, we exclude extreme observations where TID is outside of the $5^{\text {th }}$ and $95^{\text {th }}$ percentile of sample. The results without these exclusions, though, are similar to those shown here.

As can be seen in columns (3) and (6), the coefficients on the IVs are positive and statistically significant. Thus, the results affirm that both the fee and the weather disruption variables are valid IVs for TID. Given a median TID of 16 months, the point estimates imply that a 1 cent (in 1983 dollar) reduction in the per page document fee, or a 17 percent decrease from its median of 7 cents, is associated with a reduction in TID roughly between 8 and 57 days, 
depending on the specifications. A one-day increase in the incidence of severe weather is associated with 17 to 29 more days in TID. One factor contributing to the size of these results is that while most of the inclement weather events we cited were short, they likely had lingering effects because we included only extreme weather events. For instance, a severe snow storm might last only a few days, but could lead to over a week or more of work stoppage and transportation delays. Second, rescheduling court dates is difficult and requires coordinating among the judge, various lawyers, and other relevant parties and can result in extended delays, especially around holiday periods. Finally, bankruptcy courts, which also handle the rapid growth of personal bankruptcy filings, may have had to reschedule missed court dates to weeks after the originally scheduled date.

The results also reveal other determinants of TID. First, among the bankruptcy complexity variables, the coefficient on the dummy for whether a firm defaulted and filed for bankruptcy mainly as a result of litigation is positive and significant in all but the last specifications. The point estimates imply that TID of the bankruptcies triggered by litigation, ceteris paribus, were about 20 to 40 percent ( 3 to 7 months) longer than that of other bankruptcies. Other complexity proxies, such as the number of debt classes, union membership, and firm size, are insignificant. Second, industry appears to matter for TID, as the coefficient on the dummy variable for whether the firm is in the natural resource, gas, or utility industries is positive and significant in all but one specification. The point estimates show that on average, bankrupt firms in those industries spent about 20 to 60 percent ( 3 to 9 months) longer in default than firms in other industries. Third, we find that when firms entered bankruptcy in "good" or improving economic conditions, as captured, respectively, by the level and changes to the 3month T-bill rate and term premium, they tended to spend less time in default. Interestingly, we 
also find that bankrupt firms spent less time in default if the median industry leverage increased over their default. We conjecture that increasing industry leverage may signal easing conditions of external financing, which in general helps bankrupted firms obtain exit financing. In addition, TID is decreasing in high-yield bond spreads at the time of default, but results on changes in high-yield spreads are mixed. Finally, TID appears uncorrelated with the two judge-related variables and both firm and industry profitability measures.

\section{Analysis of Bond Recovery Rate}

\section{A. Basic Results}

Table 3 presents results from the cross-sectional analyses of bond recovery rates. Column (1) shows an OLS regression of bond recovery rates on actual TID and a list of control variables. The control variables used are the same as those in Column (1) of Table 2, plus two dummy variables indicating bond seniority. The standard errors of the estimates shown in this and all subsequent tables are calculated by allowing correlation between the bonds issued by the same firm but independence across firms. The OLS regression indicates that the coefficient on TID is negative and statistically significant, consistent with the conventional view that TID is costly to restructuring. ${ }^{12}$ In addition, bond recovery rates decrease with larger high-yield spreads and the presence of multiple judges, but they increase with the change in industry market-to-book ratio, the level and the change in term structure, and bond seniority and security.

Column (2) is the same OLS regression as the specification in Column (1) but the sample is restricted to those with nonmissing values for the weather disruption variable. As discussed earlier, because weather data are only available between 1993 and 2002, the sample size is about halved in (2). However, the coefficient of TID is still negative and statistically significant using

\footnotetext{
${ }^{12}$ This result is similar in sign and significance to that of Acharya et al. (2004). The magnitude is also similar after controlling for the fact that Acharya et al. measure TID in terms of years as opposed to months.
} 
this smaller sample. Most other results in Column (1) continue to hold: the exceptions are that the coefficients of the level and change in the term structure, while still positive, are insignificant, and that the coefficient of judge tenure becomes significant. Overall, the results in Columns (1) and (2) suggest that the sample restriction imposed by the use of the weather variable is not important.

Using the same sample as in Column (2), we now use our NLLIML method to jointly estimate equations (1) and (2) with document fee and weather disruption as IVs to TID. The estimated coefficients of equation (1) are reported in Column (3). The results highlight the importance of instrumenting for TID. While the coefficient of TID is still negative, it is not statistically significant. Results on other variables, however, are similar to those in Column (2).

We next test if the impact of TID on recovery rate is nonlinear by adding TID $^{2}$ to Column (3). As shown in Column (4), the coefficients on both TID and TID $^{2}$ are significant. Moreover, the point estimate implies that bond recovery rates increase in the beginning of a restructuring process but decrease when a bankrupt firm spends over 19 months in default (with a standard error of 4.7 months), suggesting that there exists an optimal duration for restructuring a bankrupt firm. It is interesting to note that the median (average) TID in our sample is just over 16 (19) months, suggesting that the average bankrupt firm spent about an optimal time in restructuring. However, a significant number of firms are far away from their optimal time in default. In particular, we calculate a two-standard-deviation band around the estimated optimal default duration of 19 months and comparing it to the distribution of TID in our total sample. Roughly 22 percent of the sample has default durations which fall below the band (i.e. their TID is significantly below the optimal) and 24 percent has durations that run above the band (i.e. their 
TID is well above the optimal). Other results with this nonlinear specification are similar to those in Column (3), except that high-yield spreads are no longer insignificant.

As we mentioned earlier, we have already excluded the observations whose TID is outside of the $5^{\text {th }}$ and $95^{\text {th }}$ percentile of sample TID to reduce the impact of extreme values. However, one might still be concerned about the impact of the skewed distribution of TID on our estimates. To evaluate this concern, we re-estimate the model in Column (3) but with instrumented $\log (\mathrm{TID})$ as the dependent variable, and the results are shown in Column (5). As in Column (3), the coefficient on the instrumented $\log$ (TID) is not significant, and the estimates on other variables are also similar to those shown in Column (3).

The results in Table 3 also reveal that other bankruptcy process variables (in addition to TID) affect bond recovery rates. First, multiple-judge dummy is always negative and statistically significant -- having multiple judges reduces bond recovery rate from 14 to 20 percent of par value. In addition, judge tenure is always positive and, in most cases, statistically significant -- a one-year increase in judge tenure is associated with a 0.75 to 1 percent of par increase in recovery rate. Thus, judge experience and expertise may contribute to the success of reorganization, and information vital to an efficient reorganization may be lost when there is a change in the presiding judge.

Our results also reveal other determinants of recovery. First, not surprisingly, bond recovery rates increase in bond seniority and security. Recovery rates on senior secured bonds are about 34 percent of par and those on senior unsecured bonds about 19 percent of par higher than bonds of other classes. Second, industry and macroeconomic conditions also matter for recovery rates. In particular, recovery rates are higher when the industry market-to-book ratio 
increased over the bankruptcy period, and they are lower if the firm defaulted when high-yield spreads were higher.

\section{B. Robustness}

To further check the robustness of the above results, we conduct two additional experiments. First, we include firm-level financial variables as additional independent variables. The results are reported in Table 4. Column (1) shows the results of the OLS regression without firm-level financial variables but with a large sample, carried over from Column (2) of Table 3. Column (2) shows results from an OLS regression of REC on TID with the firm-level financial variables. While the sample is nearly halved, the coefficient on TID is still negative, significant, and similar in magnitude to that in Column (1). Results from maximum likelihood estimations with the IVs are reported in Columns (3)-(5) for the same specifications shown in Table 3. None of the estimations shows a statistically significant coefficient on TID. However, the coefficient on the change of high-yield spread is significantly negative and the coefficients on the level and changes in the industry market-to-book ratio are significantly positive. Finally, none of the firmlevel financial variables are statistically significant.

We next conduct an analysis of firm-level bond recovery rates, defined as the average recovery rate on a firm's all bonds (up to data availability) using a bond's par values as weights. The exercise addresses the possibility that our results reflect mainly the experience of a few firms with many bonds. The results, reported in Table 5, are similar to those in Table 3. Specifically, Columns (1) and (2) show that with linear specifications, the coefficient of TID is statistically significant in the OLS estimation but insignificant in the IV estimation. The point estimates in Column (3) indicate that the firm-level bond recovery rates increase with 
instrumented TID in the beginning of a restructuring process but decrease with TID after 27 months in default (with a standard error of 4.2 months). The coefficient on instrumented $\log$ (TID), shown in Column (4), is again insignificant. The results in Column (5) show that the inclusion of firm-level financial variables has little impact on the results, despite resulting in an almost halved sample. The results in Table 5 also confirm other results in Table 3. In particular, REC is lower when the bankruptcy involves multiple judges, and REC increases with industry market-to-book ratio and term structure.

\section{Does the Optimal Time Vary?}

To answer this question, we augment the specifications shown in Table 3 with variables that interact both TID and TID $^{2}$ with firm, industry, and macroeconomic variables. Additional time spent in bankruptcy may be more beneficial for relatively complex cases—allowing for a careful check of creditors, a well-conceived restructuring plan, and a richer set of buyers for firm assets - and for firms defaulted during a recession — allowing for the turnaround of the economy.

The results from specifications that include the TID interaction terms are presented in Table 6. In Column (1)-(6), TID and TID $^{2}$ are interacted, respectively, with dummy variables indicating: (1) a financial firm; (2) multiple creditor classes; (3) tort-triggered filings; (4) default during a recession; (5) being in an industry in which the ratio of unionized employees to total employees is below the first (i.e., bottom) quartile of the distribution of such ratios, and, in the same specification, being in an industry that is above the fourth quartile of that distribution; (6) being below the first quartile (i.e., bottom) of the firm-size (total amount of defaulted debt) distribution, and, in the same specification, being above the fourth quartile of that distribution. To save space, the coefficients on other control variables are not shown. 
The results indicate that the optimal time spent restructuring varies across three different dimensions. In the first specification, the coefficients on TID and $\mathrm{TID}^{2}$ are jointly significant, as are the coefficients on their interactions with the financial firm dummy variable. The point estimates imply that financial firms have an optimal time in default of 17 months and nonfinancial firms have an optimal time of 18 months. In the fifth specification, the coefficients on the interaction terms with the above-the-fourth-quartile-union-membership variable are also jointly significant; however, the coefficients on TID and TID $^{2}$ are not jointly significant, nor are their interactions with the below-the-fourth-quartile-union-membership variable. In the sixth specification, the coefficients on TID and $\mathrm{TID}^{2}$ are jointly significant, as are the coefficients on their interactions with the below-the-first-quartile-of-firm-size variable. The point estimates imply an optimal time in default of 15 months for firms below the first quartile of the firm-size distribution and 21 months for other firms. ${ }^{13}$ Thus, smaller firms do not appear to benefit as much as larger firms from additional restructuring time.

\section{Additional Evidence: The Impact of TID on the Likelihood of Reentering Bankruptcy}

One indicator frequently used to measure the success of a restructuring is whether the company ends up re-filing for bankruptcy or conducting another restructuring (e.g., LoPucki and Kalin (2001)) within a short period of time. In cases of "Chapter 22s" or even "Chapter 33s," one reason cited for the repeated filing is that the company's time in bankruptcy was too short, not too long (e.g., Leone (2005) and Nathan, Cargill, and Yar (2005)).

\footnotetext{
${ }^{13}$ The impact of being below the first quartile of the size distribution on optimal time is treated as zero, given the insignificance of the relevant coefficients.
} 
To examine this issue, we adapt our maximum likelihood method to obtain an estimate for the impact of TID on the likelihood of refiling. Specifically, we assume that the incidence of refiling is determined according to a latent variable $y^{*}$ :

$$
y^{*}=\alpha+\beta \mathrm{X}+\gamma \mathrm{TID}+\varepsilon,
$$

such that we observe a refiling, denoted by $I=1$, if $y^{*} \geq 0$ and no refiling, denoted by $I=0$, otherwise. Assume that TID still follows equation (2). Using the same notation as above and assuming again that $\varepsilon$ and $\mathrm{v}$ follow a bivariate normal distribution with standard deviations $\sigma_{\epsilon}$, $\sigma_{v}$, and correlation $\rho$, and probability density function $f(\varepsilon, v)$, then the quasi-log-likelihood function is

$$
\ln f=\Sigma_{\mathrm{i}} p \ln \operatorname{Prob}(\mathrm{TID} \geq s)+(1-p)\left[\ln f(v)+I \ln \operatorname{Prob}\left(y^{*} \geq 0 \mid v\right)+(1-I) \ln \operatorname{Prob}\left(y^{*}<0 \mid v\right)\right],
$$
where $f(v)$ is the marginal probability density function of $v$. Since $\varepsilon$ conditional on $v$ is normally distributed with mean $v \rho \sigma_{\epsilon} \sigma_{v}$ and variance $\sigma_{\epsilon}^{2}\left(1-\rho^{2}\right)$,

$$
\operatorname{Prob}\left(y^{*} \geq 0 \mid v\right)=\Phi\left(\left(\alpha+\beta \mathrm{X}+\gamma \mathrm{TID}+v \rho \sigma_{\epsilon} \sigma_{v}\right) /\left(\sigma_{\epsilon}\left(1-\rho^{2}\right)^{0.5}\right)\right) .
$$

Note that the coefficients of $y^{*}$ equation can only be identified up to a fraction of $\sigma_{\epsilon}$. So we normalize $\sigma_{\epsilon}=1$.

The control variables, $X$, include bankruptcy complexity variables, such as number of debt classes and tort, and industry and macro financial variables. The judge tenure variable and firm-level financial variables are excluded, as the estimation fails to achieve convergence mainly due to the much smaller sample with their inclusion. The dependent variable is the incidence of refiling within five years after emerging from bankruptcy. The sample used in the estimation has 245 initial bankruptcies. Among these events, 17, or 7 percent of the sample, were followed by a refiling within five years after the emergence. 
The results are shown in Table 7. Column (1) presents the estimated coefficients of a probit regression of refiling on TID without using IVs. Columns (2)-(4) contain maximum likelihood estimations from alternative specifications that use IVs for TID. The only significant relationship between TID and the probability of refiling is found in the nonlinear specification, the results from which are shown in Column (3). The point estimate shows that the likelihood of refiling decreases in TID when TID is small but increases when TID reaches 32 months (with a standard error of 8.4 months), still within one standard deviation of the mean TID. Again, bondholders appear to benefit in the beginning of the restructuring process but are hurt if the process becomes too long.

\section{Conclusion}

In this paper we study the impact of time spent in default on bankruptcy costs, as measured by bond recovery rates and the likelihood of reentering bankruptcy. Our main contribution to the literature is to recognize and address the endogeneity of time spent in default. We construct two instrumental variables to extract exogenous variations in time in default - one capturing the disrupting effects of severe weather disturbances, the other capturing exogenous technological improvements in the processing of bankruptcy cases. Earlier work and conventional wisdom owns that time is always costly. Our results confirm this view - but only for OLS regressions. Once the problem of endogeneity is properly addressed we get a very different result. We find that bond recovery rates increase with time in the initial stage of a restructuring process and decrease only if a firm stays in bankruptcy for an extended period. In the same spirit, the likelihood of a firm reentering bankruptcy within five years of emergence decreases initially and then increases with time spent in default. This suggests that there exists 
an optimal time for firms to remain under bankruptcy protection. In addition, we provide some evidence that this optimal time may vary with certain firm characteristics.

Our paper makes two additional contributions to the literature. First, we provide an indepth examination of default duration across both time and firms using a much larger sample than in previous studies. We find that time in default is significantly related to whether the bankruptcy is triggered by litigation, the industry and macroeconomic conditions at the time of default, and the change in these conditions over the duration of the default.

Second, we provide evidence that other aspects of the bankruptcy process have significant impacts on creditor return. In particular, the nature of the judge matters for the efficiency of the bankruptcy process. Our results show that experienced judges improve creditor returns while the switching of judges during the case, or the existence of more than one judge simultaneously, worsens the outcome for creditors and increases the likelihood of a firm reentering bankruptcy.

Our results have important policy implications for the reform of existing bankruptcy systems, the design of new systems for emerging economies, and the drafting of plans for international courts such as the IMF's Sovereign Debt Restructuring Mechanism. Although legal and economic scholars have compared bankruptcy systems across countries, empirical evidence on the efficiency of these systems remains limited. Recent bankruptcy legislation both in the United States and abroad (for example, Brazil) has emphasized reducing time in default. Evidence from this paper suggests that the impact of the efforts to minimize time spent in bankruptcy for its own sake is not always beneficial to creditors. In particular, there appears to be some optimal time that a firm should spend in bankruptcy process in the sense that time adds to firm values in the initial stage of reorganization but is detrimental if a firm stays under the 
protection of bankruptcy too long. The risk of setting a fixed limit on the reorganization time, as suggested in the recent U.S. bankruptcy reform, is that such limits may be too low compared to the optimal time for firms with complex cases. ${ }^{14}$ Our results would also imply that contracts that encourage bankruptcy participants to expedite workouts must be carefully structured or they may be inappropriately targeted.

On the other hand, there appears to be a positive benefit to having experienced judges. This suggests that shorter term limits on judges would be ill-advised. Furthermore, our results suggest that judge switching during a bankruptcy case or the existence of multiple judges on the same case also reduces return for creditors, indicating that systems that rely on rotation or panels of judges as well as the Delaware-type visiting judge system may be less optimal.

${ }^{14}$ The ultimate effects of the new time limits imposed by the BCAPA will depend on the reaction of the various parties to the changes, as suggested by the well-known Lucas critique. A significant change in the behavior of the participants may alter the relationship between TID and firm value if such limits become binding constraints. Indeed, many observers suggest that firms may delay longer in filing for bankruptcy or rely more on out-of-court restructuring methods or pre-packaged Chapter 11. Thus, future research should examine carefully how the new law alters the default and bankruptcy process. 


\section{References}

Acharya, V. V., S. T. Bharath, and A. Srinivasan (2004), "Understanding the Recovery Rates on Defaulted Securities," mimeo, London Business School, University of Michigan, and University of Georgia.

Altman, Edward I. (1984), "A Further Empirical Investigation of the Bankruptcy Cost Question," Journal of Finance, vol. 39, iss. 4, pp. 1067-89.

Altman, Edward L., Brooks Brady, Andrea Resti, and Andrea Sironi (2005), "The Link between Default and Recovery Rates: Theory, Empirical Evidence and Implications," Journal of Business, vol. 78, no. 6.

Amemiya, Takeshi (1985), Advanced Econometrics, Harvard University Press, Cambridge, Massachusetts.

Andrade, G. and S. N. Kaplan (1998), "How Costly is Financial (Not Economic) Distress? Evidence from Highly Leveraged Transactions that Become Distressed," Journal of Finance, 53, pp. 1443-1494.

Ayotte, K. M. and D. A. Skeel, Jr. (2002), "Why Do Distressed Companies Choose Delaware? Venue Choice and Court Experience in Bankruptcy," mimeo, Columbia University and University of Pennsylvania Law School.

Baird, Douglas G. and Morrison, Edward R. (2001), "Bankruptcy Decision Making," Journal of Law, Economics, and Organization, vol. 17, pp. 356-372.

Baird, Douglas G. and Morrison, Edward R. (2005), "Serial Entrepreneurs and Small Business Bankruptcies," University of Chicago Law \& Economics, Olin Working Paper No. 236; Columbia Law and Economics Working Paper No. 265.

Bandopadhyaya, A. (1994), "An Estimation of the Hazard Rate of Firms in Chapter 11 Protection," Review of Economics and Statistics, May, pp. 346-350.

Bermant, Gordon and Ed Flynn (1998), "Bankruptcy by the Numbers — Outcomes of Chapter 11 Cases: U.S. Trustee Database Sheds New Light on Old Questions," The ABI Journal, vol. XVII, no. 1.

Betker, Brian L. (1997), “The Administrative Costs of Debt Restructurings: Some Recent Evidence." Financial Management, vol. 26, no. 4, pp. 56-68.

Bris, A., I. Welch, N. Zhu (2004), "The Costs of Bankruptcy: Chapter 7 Cash Auctions vs. Chapter 11 Bargaining," Yale ICF Working Paper No. 04-13.

Carey, Mark and Michael Gordy, (2004), "Measuring Systematic Risks in Recoveries in Defaulted Debt" mimeo, Federal Reserve Board. 
Chen, Nan (2003), "Chapter 11, Private Workouts and Corporate Debt Pricing under Asymmetric Information," Graduate School of Business, Columbia University.

Covitz, Daniel and Song Han (2005), "An Empirical Analysis of Bond Recovery Rates: Exploring a Structural View of Default," The Federal Reserve Board Finance and Economics Discussion Series, 2005-10.

Diamond, Douglas W. (1993), "Seniority and Maturity of Debt Contracts," Journal of Financial Economics, vol. 33, iss. 3, pp. 341-68.

Eisenberg, Theodore and Lynn M. LoPucki (1998), "Shopping for Judges: An Empirical Analysis of Venue Choice in Large Chapter 11 Reorganizations," Cornell Law Review, vol. 84, pp. 967-1003.

Franks, J. and W. Torous (1989), "An Empirical Investigation of U.S. Firms in Reorganization," Journal of Finance, 44, pp. 747-770.

Gilson, Stuart (1997), "Transactions Costs and Capital Structure Choice: Evidence from Financially Distressed Firms," Journal of Finance, vol. LII, no. 1, pp. 161-96.

Hart, Oliver (2000), “Different Approaches to Bankruptcy,” NBER Working Paper 7921.

Hart, Oliver and John Moore (1995), "Debt and Seniority: An Analysis of the Role of Hard Claims in Constraining Management," American Economic Review, vol. 85, iss. 3, pp. 567-85.

Haugen, Robert A. and Lemma W. Senbet (1978), "The Insignificance of Bankruptcy Costs to the Theory of Optimal Capital Structure," Journal of Finance, vol. 33, iss. 2, pp. 383-93.

Helwege, Jean (1999), “How Long Do Junk Bonds Spend in Default?” Journal of Finance, 54, pp. 341-357.

Hirsch, Barry T. and David A. Macpherson (2003), "Union Membership and Coverage Database from the Current Population Survey: Note," Industrial and Labor Relations Review, vol. 56, no. 2, pp. 349-54.

Hotchkiss, Edith S. (1995), "Post-bankruptcy Performance and Management Turnover," Journal of Finance, vol. L., no. 1, pp. 3-21.

Jensen, Michael C. (1989), “The Eclipse of the Public Corporation,” Harvard Business Review 5, 61-74.

Jensen, Michael C. (1991), "Corporate Control and the Politics of Finance," in The New Corporate Finance: Where Theory Meets Practice, D. H. Chew, editor, pp. 620-640.

Jensen, Michael C. (1993), "The Modern Industrial Revolution, Exit, and the Failure of Internal Control Systems," Journal of Finance, vol. 48, iss. 3, pp. 831-80. 
Krueger, A. (2002), “The Need for a Sovereign Debt Restructuring Mechanism,” International Monetary Fund.

Leone, Marie (2005), "What You Don't Know about the Bankruptcy Law," May 5, http://www.CFO.com.

Li., Kai (1999), "Bayesian Analysis of Duration Models: An Application to Chapter 11 Bankruptcy,” Economics Letters 63, pp. 305-312.

LoPucki, Lynn M. (2005), Courting Failure: How Competition for Big Cases Is Corrupting the Bankruptcy Courts," The University of Michigan Press.

LoPucki, L. M. and J. W. Doherty (2004), “The Determinants of Professional Fees in Large Bankruptcy Organization Cases," The Journal of Empirical Legal Studies, 1, 111-1142.

LoPucki, L. M. and S. D. Kalin (2001), "The Failure of Public Company Bankruptcies in Delaware and New York: Empirical Evidence of a 'Race to the Bottom," Vanderbilt Law Review, 54, 231-82.

Maksimovic, V. and G. Phillips (1998), "Asset Efficiency and Reallocation Decisions of Bankrupt Firms," Journal of Finance, 53, pp. 1495-1533.

Nathan, Bruce S., Scott Cargill, and Joseph M. Yar (2005), "Bankruptcy Abuse Prevention and Consumer Protection Act of 2005: Landmark Business and Other Bankruptcy Changes," Lowenstein Sandler PC.

Opler, Tim C. and Sheridan Titman (1994), "Financial Distress and Corporate Performance," Journal of Finance, vol. 49, iss. 3, pp. 1015-40.

Orbe, Jesus, Eva Ferreira, and Vicente Nunez-Anton (2002), "Length of Time Spent in Chapter 11 Bankruptcy: A Censored Partial Regression Model," Applied Economics, 34, pp. 1949-1957.

Shleifer, Andrei and Robert Vishny (1992), "Liquidation Values and Debt Capacity: A Market Equilibrium Approach," Journal of Finance, vol. 47, pp. 1343-1366.

Skeel, Jr., D. A. (2003), “Creditors' Ball: The "New” New Corporate Governance in Chapter 11," University of Pennsylvania Law Review, 152, pp. 917-951.

Smith, D. C. and P. Strömberg (2004), "Maximizing the Value of Distressed Assets: Bankruptcy Law and the Efficient Reorganization of Firms," mimeo, Federal Reserve Board and University of Chicago.

Thorburn, K. (2000), “Bankruptcy Auctions: Costs, Debt Recovery, and Firm Survival,” Journal of Financial Economics, 58, pp. 337-368. 
Varma, Praveen and Richard Cantor (2005), "Determinants of Recovery Rates on Defaulted Bonds and Loans for North American Corporate Issuers: 1983-2003," The Journal of Fixed Income, March.

Warner, J. A. (1977), “Bankruptcy Costs: Some Evidence,” Journal of Finance, pp. 337-347.

Weiss, L. (1990), "Bankruptcy Resolution: Direct Costs and Violations of Absolute Priority," Journal of Financial Economics, 27, pp. 419-446.

Yue, L. (2002), Kmart Lines up Cash for New Boss, Detroit Free Press, April 10, page 1A. 
Table 1

Summary Statistics for Key Variables

(U.S. firms that filed for bankruptcy in 1983-2002)

\begin{tabular}{|c|c|c|c|c|c|}
\hline Variable name & N. obs* & Mean & Std dev. & Median & Source** \\
\hline \multicolumn{6}{|l|}{ Bond characteristics } \\
\hline Senior secured (=1 if yes) & 2819 & 0.16 & 0.36 & 0 & Moody's, S\&P \\
\hline Senior unsecured ( $=1$ if yes) & 2819 & 0.39 & 0.49 & 0 & Moody's, S\&P \\
\hline Recovery rate at resolution (REC, \% of par) & 1430 & 44.71 & 43.18 & 30.00 & $\mathrm{~S} \& \mathrm{P}$ \\
\hline REC discounted by high-yield index at default & 1430 & 35.39 & 33.69 & 24.31 & S\&P, Merrill Lynch Master II \\
\hline \multicolumn{6}{|l|}{ Firm characteristics } \\
\hline Log(total assets, \$million in 1983 dollar) & 445 & 5.80 & 1.50 & 5.70 & Compustat \\
\hline Tangible assets/total assets (\%) & 435 & 38.44 & 23.42 & 34.73 & Compustat \\
\hline Book leverage (=total debt/assets, $\%)$ & 445 & 92.65 & 142.73 & 71.63 & Compustat \\
\hline Return on assets $(\%)$ & 404 & -0.28 & 4.75 & 0.74 & Compustat \\
\hline Financial firm $(=1 \text { if yes })^{\mathrm{a}}$ & 1045 & 0.09 & 0.29 & 0 & Moody's, Compustat \\
\hline Energy/utility firm (=1 if yes $)^{\mathrm{a}}$ & 1045 & 0.08 & 0.27 & 0 & Moody's, Compustat \\
\hline \multicolumn{6}{|c|}{ Industry characteristics (median values for 2-digit SIC code) } \\
\hline Industry union membership at default (\%) & 983 & 12.79 & 10.99 & 10.23 & www.unionstats.com \\
\hline Industry book leverage at default (\%) & 984 & 30.50 & 13.06 & 31.36 & Compustat \\
\hline Changes in industry book leverage & 882 & -0.88 & 4.74 & -0.34 & \\
\hline Industry return on assets at default (\%) & 984 & 2.20 & 1.49 & 2.41 & Compustat \\
\hline Changes in industry return on assets & 882 & 0.14 & 1.04 & 0.05 & \\
\hline Industry market/book ratio at default (\%) & 984 & 131.80 & 36.00 & 123.97 & Compustat \\
\hline Changes in industry market-to-book ratio & 882 & 2.83 & 26.11 & 0.87 & \\
\hline \multicolumn{6}{|l|}{ Macroeconomic conditions } \\
\hline 3-month T-bill rate at default (\%) & 1045 & 5.12 & 1.96 & 5.29 & www.federalreserve.gov \\
\hline Term premium at default ( $10 \mathrm{yr}-3-\mathrm{m}$ Treasury) & 1045 & 1.48 & 1.17 & 1.32 & www.federalreserve.gov \\
\hline Changes in 3 -month T-bill rate & 931 & -1.17 & 1.94 & -0.70 & \\
\hline Changes in term premium & 931 & 0.53 & 1.47 & 0.48 & \\
\hline High-yield spreads at default (\%) & 1045 & 6.20 & 1.95 & 5.94 & Merrill Lynch Master II \\
\hline Changes in high-yield spreads & 931 & -0.12 & 2.18 & -0.15 & \\
\hline \multicolumn{6}{|l|}{ Bankruptcy complexity and process } \\
\hline Time in default (TID, in months, ex. pending cases) ${ }^{b}$ & 940 & 19.47 & 15.14 & 16.27 & Moody's, S\&P, Factiva \\
\hline Default triggered by tort $(=1 \text { if yes })^{\mathrm{c}}$ & 1045 & 0.10 & 0.30 & 0 & BY\&A, Lopucki WebBRD \\
\hline Number of seniority classes & 973 & 1.88 & 0.97 & 2 & Moody's, S\&P \\
\hline Multiple or switching judges ( $=1$ if yes) & 790 & 0.03 & 0.18 & 0 & Factiva \\
\hline Judge tenure in years & 404 & 8.74 & 6.32 & 7.00 & Bloomberg, Factiva \\
\hline Document fee per page (in 1983 dollar) & 1045 & 0.16 & 0.15 & 0.07 & Admin. Off. of US Courts \\
\hline Number of days with inclement weather & 325 & 2.50 & 3.09 & 1 & NCDC, court records \\
\hline Inclement weather as a fraction of TID (\%) & 318 & 0.47 & 0.58 & 0.31 & \\
\hline Case pending as of $7 / 30 / 2004$ (=1 if yes) & 984 & 0.04 & 0.19 & 0 & Factiva \\
\hline
\end{tabular}

Notes:

* Number of observations is the number of bonds for contract characteristics variables and the number of firms for all other variables.

** BY\&A: the Bankruptcy Yearbook \& Almanac, various issues.

${ }^{a}$ The number of firms with nonmissing values for these two variables is larger than the number of firms with nonmissing values for industry financial variables. This is because we determine whether a firm is a financial or an energy/utility firm based on both SIC code and Moody's industry classifications (when the firm's SIC code is missing) but create the industry financial variables based on SIC code only.

${ }^{b}$ TID is the period from a firm's first default incident to the resolution of its bankruptcy filing.

c "Tort" is broadly defined as whether a default is triggered mainly by a "non-financial' reason, including accounting fraud, product liability litigation, labor contract dispute, and environmental lawsuit. 
Table 2

Determinants of Time in Default and Validity of Instrument Variables

This table shows the results of the estimations of time in default (TID) using a censored survival model with log-normal distributions. Censoring occurs if a bankruptcy case is pending at the time of the latest data collection (which is July 30, 2004). The sample consists of U.S. firms that defaulted on their publicly issued bonds and filed for bankruptcy in 1983-2002. TID equals to the length of the period from the firm's first default incident to the resolution of the bankruptcy proceeding. The two variables in bold, per page fee in real dollar for obtaining court documents and the number of days of inclement weather as a percent of TID, are the IVs used in later estimations.

Note that $*$ and $* *$ indicate that a coefficient is statistically significant at the $90 \%$ and $95 \%$ confidence levels, respectively, and that standard errors of the estimated coefficients, calculated using the Huber/White robust method, are shown in parentheses. 
Table 2 (continued)

Determinants of Time in Default and Validity of Instrument Variables

\begin{tabular}{|c|c|c|c|c|c|c|}
\hline & (1) & $(2)$ & (3) & (4) & $(5)$ & $(6)$ \\
\hline Log(assets) & & & & $\begin{array}{l}-0.03 \\
(0.06)\end{array}$ & $\begin{array}{l}-0.05 \\
(0.06)\end{array}$ & $\begin{array}{l}-0.05 \\
(0.07)\end{array}$ \\
\hline Tangible assets/total assets & & & & $\begin{array}{l}-0.00 \\
(0.00)\end{array}$ & $\begin{array}{l}-0.00 \\
(0.00)\end{array}$ & $\begin{array}{l}0.01 * * \\
(0.00)\end{array}$ \\
\hline Firm book leverage & & & & $\begin{array}{l}-0.00^{* *} \\
(0.00)\end{array}$ & $\begin{array}{c}-0.00^{* *} \\
(0.00)\end{array}$ & $\begin{array}{l}-0.00 \\
(0.00)\end{array}$ \\
\hline Return on assets & & & & $\begin{array}{l}-0.00 \\
(0.01)\end{array}$ & $\begin{array}{l}-0.00 \\
(0.01)\end{array}$ & $\begin{array}{l}-0.01 \\
(0.01)\end{array}$ \\
\hline Default due to tort & $\begin{array}{l}0.34 * * \\
(0.11)\end{array}$ & $\begin{array}{l}0.21^{* *} \\
(0.11)\end{array}$ & $\begin{array}{l}0.35^{* *} \\
(0.13)\end{array}$ & $\begin{array}{l}0.43^{* *} \\
(0.19)\end{array}$ & $\begin{array}{c}0.37^{*} \\
(0.19)\end{array}$ & $\begin{array}{c}0.39 \\
(0.24)\end{array}$ \\
\hline Number of creditor classes & $\begin{array}{l}-0.00 \\
(0.03)\end{array}$ & $\begin{array}{c}0.01 \\
(0.03)\end{array}$ & $\begin{array}{c}0.02 \\
(0.04)\end{array}$ & $\begin{array}{c}0.00 \\
(0.06)\end{array}$ & $\begin{array}{c}0.01 \\
(0.06)\end{array}$ & $\begin{array}{c}0.09 \\
(0.07)\end{array}$ \\
\hline Energy or utility company & $\begin{array}{c}0.27 * \\
(0.15)\end{array}$ & $\begin{array}{c}0.26^{*} \\
(0.15)\end{array}$ & $\begin{array}{l}0.36^{* *} \\
(0.16)\end{array}$ & $\begin{array}{l}0.63^{* *} \\
(0.28)\end{array}$ & $\begin{array}{l}0.58^{* *} \\
(0.28)\end{array}$ & $\begin{array}{l}-0.11 \\
(0.42)\end{array}$ \\
\hline Financial company & $\begin{array}{c}0.18 \\
(0.15)\end{array}$ & $\begin{array}{c}0.18 \\
(0.15)\end{array}$ & $\begin{array}{c}0.13 \\
(0.17)\end{array}$ & $\begin{array}{c}0.15 \\
(0.36)\end{array}$ & $\begin{array}{l}0.25 \\
(0.36)\end{array}$ & $\begin{array}{l}0.76^{* *} \\
(0.38)\end{array}$ \\
\hline Union membership in industry & $\begin{array}{c}0.00 \\
(0.00)\end{array}$ & $\begin{array}{c}0.00 \\
(0.00)\end{array}$ & $\begin{array}{c}0.01 \\
(0.00)\end{array}$ & $\begin{array}{c}0.00 \\
(0.01)\end{array}$ & $\begin{array}{c}0.00 \\
(0.01)\end{array}$ & $\begin{array}{c}0.01 \\
(0.01)\end{array}$ \\
\hline Industry leverage & $\begin{array}{l}-0.00 \\
(0.00)\end{array}$ & $\begin{array}{l}-0.00 \\
(0.00)\end{array}$ & $\begin{array}{l}-0.00 \\
(0.00)\end{array}$ & $\begin{array}{l}-0.00 \\
(0.01)\end{array}$ & $\begin{array}{l}-0.01 \\
(0.01)\end{array}$ & $\begin{array}{l}-0.02^{* *} \\
(0.01)\end{array}$ \\
\hline Industry market-to-book ratio & $\begin{array}{l}-0.00 \\
(0.00)\end{array}$ & $\begin{array}{l}-0.00 \\
(0.00)\end{array}$ & $\begin{array}{l}-0.00 \\
(0.00)\end{array}$ & $\begin{array}{c}0.00 \\
(0.00)\end{array}$ & $\begin{array}{c}0.00 \\
(0.00)\end{array}$ & $\begin{array}{l}-0.00^{*} \\
(0.00)\end{array}$ \\
\hline Industry return on assets & $\begin{array}{l}-0.02 \\
(0.04)\end{array}$ & $\begin{array}{l}-0.01 \\
(0.03)\end{array}$ & $\begin{array}{l}-0.03 \\
(0.04)\end{array}$ & $\begin{array}{l}-0.03 \\
(0.05)\end{array}$ & $\begin{array}{l}-0.02 \\
(0.05)\end{array}$ & $\begin{array}{l}-0.11 \\
(0.07)\end{array}$ \\
\hline Change in industry leverage & $\begin{array}{l}-0.01 \\
(0.01)\end{array}$ & $\begin{array}{l}-0.01 \\
(0.01)\end{array}$ & $\begin{array}{l}-0.03^{* *} \\
(0.01)\end{array}$ & $\begin{array}{l}-0.02 \\
(0.01)\end{array}$ & $\begin{array}{l}-0.02 \\
(0.01)\end{array}$ & $\begin{array}{l}-0.05^{* *} \\
(0.01)\end{array}$ \\
\hline Change in industry return on assets & $\begin{array}{c}0.05 \\
(0.04)\end{array}$ & $\begin{array}{c}0.05 \\
(0.04)\end{array}$ & $\begin{array}{c}0.01 \\
(0.05)\end{array}$ & $\begin{array}{c}0.06 \\
(0.06)\end{array}$ & $\begin{array}{c}0.05 \\
(0.06)\end{array}$ & $\begin{array}{l}-0.04 \\
(0.10)\end{array}$ \\
\hline Change in industry $\mathrm{mkt} /$ book ratio & $\begin{array}{l}-0.00 \\
(0.00)\end{array}$ & $\begin{array}{l}-0.00 \\
(0.00)\end{array}$ & $\begin{array}{l}-0.00 \\
(0.00)\end{array}$ & $\begin{array}{c}0.00 \\
(0.00)\end{array}$ & $\begin{array}{c}0.00 \\
(0.00)\end{array}$ & $\begin{array}{l}-0.00 \\
(0.00)\end{array}$ \\
\hline Multiple/switching judges & $\begin{array}{c}0.27 \\
(0.18)\end{array}$ & $\begin{array}{c}0.28 \\
(0.17)\end{array}$ & $\begin{array}{c}0.26 \\
(0.17)\end{array}$ & $\begin{array}{c}0.23 \\
(0.26)\end{array}$ & $\begin{array}{c}0.20 \\
(0.26)\end{array}$ & $\begin{array}{c}0.14 \\
(0.27)\end{array}$ \\
\hline Tenure of bankruptcy judge & $\begin{array}{l}-0.00 \\
(0.01)\end{array}$ & $\begin{array}{l}-0.00 \\
(0.01)\end{array}$ & $\begin{array}{l}-0.00 \\
(0.01)\end{array}$ & $\begin{array}{l}-0.01 \\
(0.01)\end{array}$ & $\begin{array}{l}-0.01 \\
(0.01)\end{array}$ & $\begin{array}{l}-0.00 \\
(0.01)\end{array}$ \\
\hline Yield on 3-month T-bill & $\begin{array}{c}0.06^{*} \\
(0.03)\end{array}$ & $\begin{array}{l}-0.21^{* *} \\
(0.06)\end{array}$ & $\begin{array}{l}-0.62^{* *} \\
(0.10)\end{array}$ & $\begin{array}{c}0.04 \\
(0.05)\end{array}$ & $\begin{array}{l}-0.09 \\
(0.09)\end{array}$ & $\begin{array}{l}-0.68^{* *} \\
(0.16)\end{array}$ \\
\hline Term premium & $\begin{array}{c}0.10^{*} \\
(0.05)\end{array}$ & $\begin{array}{l}-0.22 * * \\
(0.08)\end{array}$ & $\begin{array}{l}-0.73^{* *} \\
(0.13)\end{array}$ & $\begin{array}{c}0.14^{*} \\
(0.08)\end{array}$ & $\begin{array}{l}-0.02 \\
(0.12)\end{array}$ & $\begin{array}{l}-0.86^{* *} \\
(0.21)\end{array}$ \\
\hline High yield spread & $\begin{array}{c}-0.08^{* *} \\
(0.03)\end{array}$ & $\begin{array}{l}-0.11^{* *} \\
(0.03)\end{array}$ & $\begin{array}{l}-0.14 * * \\
(0.04)\end{array}$ & $\begin{array}{l}-0.07^{*} \\
(0.04)\end{array}$ & $\begin{array}{l}-0.07 \\
(0.04)\end{array}$ & $\begin{array}{l}-0.15^{* *} \\
(0.06)\end{array}$ \\
\hline Change in 3-month T-bill yield & $\begin{array}{l}-0.21^{* *} \\
(0.04)\end{array}$ & $\begin{array}{l}-0.33^{* *} \\
(0.05)\end{array}$ & $\begin{array}{l}-0.39^{* *} \\
(0.07)\end{array}$ & $\begin{array}{l}-0.26^{* *} \\
(0.07)\end{array}$ & $\begin{array}{c}-0.30^{* *} \\
(0.07)\end{array}$ & $\begin{array}{l}-0.36^{* *} \\
(0.10)\end{array}$ \\
\hline Change in term premium & $\begin{array}{l}-0.09 \\
(0.06)\end{array}$ & $\begin{array}{l}-0.25^{* *} \\
(0.06)\end{array}$ & $\begin{array}{l}-0.23 * * \\
(0.08)\end{array}$ & $\begin{array}{l}-0.09 \\
(0.09)\end{array}$ & $\begin{array}{l}-0.17^{*} \\
(0.10)\end{array}$ & $\begin{array}{l}-0.27 * * \\
(0.12)\end{array}$ \\
\hline Change in high-yield spread & $\begin{array}{l}-0.03 \\
(0.02)\end{array}$ & $\begin{array}{l}-0.05^{* *} \\
(0.02)\end{array}$ & $\begin{array}{l}0.08^{* *} \\
(0.03)\end{array}$ & $\begin{array}{l}-0.02 \\
(0.04)\end{array}$ & $\begin{array}{l}-0.03 \\
(0.04)\end{array}$ & $\begin{array}{c}0.09^{*} \\
(0.05)\end{array}$ \\
\hline Per page document fee in real dollar & & $\begin{array}{l}2.82^{* *} \\
(0.55)\end{array}$ & $\begin{array}{l}11.67^{* *} \\
(1.89)\end{array}$ & & $\begin{array}{l}1.62^{*} \\
(0.91)\end{array}$ & $\begin{array}{l}11.78^{* *} \\
(3.21)\end{array}$ \\
\hline Inclement weather as \% of TID & & & $\begin{array}{l}0.17 * * \\
(0.06)\end{array}$ & & & $\begin{array}{l}0.29 * * \\
(0.11)\end{array}$ \\
\hline Constant & $\begin{array}{l}2.91 * * \\
(0.46)\end{array}$ & $\begin{array}{l}4.35 * * \\
(0.53)\end{array}$ & $\begin{array}{l}6.28 * * \\
(0.77)\end{array}$ & $\begin{array}{c}3.06^{* *} \\
(0.75)\end{array}$ & $\begin{array}{l}3.80 * * \\
(0.85)\end{array}$ & $\begin{array}{l}7.65^{* *} \\
(1.25)\end{array}$ \\
\hline $\begin{array}{l}\text { Log-likelihood } \\
\text { Number of observations (firms) }\end{array}$ & $\begin{array}{l}-344.68 \\
357\end{array}$ & $\begin{array}{l}-332.31 \\
357\end{array}$ & $\begin{array}{l}-158.95 \\
214\end{array}$ & $\begin{array}{l}-151.23 \\
164\end{array}$ & $\begin{array}{l}-149.68 \\
164\end{array}$ & $\begin{array}{l}-74.06 \\
100\end{array}$ \\
\hline
\end{tabular}


Table 3

Impact of TID on Bond Recovery Rates

This table shows the results on the impact of TID on bond recovery rates using a nonlinear limited information maximum likelihood estimation (NLLIMLE) method as suggested in Amemiya (1985, $\S 8.1 .3)$. The sample consists of U.S. firms that defaulted on their publicly issued bonds and filed for bankruptcy in 1983-2002. The dependent variable is the bond-level recovery rate and the independent variables include contract, industry, macroeconomic, and bankruptcy complexity variables and TID. The IVs for TID include real dollar per page fee to obtain court documents and inclement weather, expressed as a fraction of TID.

Note that $*$ and $* *$ indicate that a coefficient is statistically significant at $90 \%$ and $95 \%$ confidence levels, respectively. Standard errors of the coefficients, shown in parentheses, are computed using the Huber/White robust method with an assumption that the error terms for the bonds issued by the same firm may be correlated but they are uncorrelated across firms. All specifications include a constant term, not shown. 
Table 3 (continued)

Impact of TID on Bond Recovery Rates

\begin{tabular}{|c|c|c|c|c|c|}
\hline Independent variables & (1)-OLS & (2)-OLS & (3)-MLE & (4)-MLE & (5)-MLE \\
\hline Sr. secured & $\begin{array}{l}30.25^{* *} \\
(5.45)\end{array}$ & $\begin{array}{l}33.76^{* * *} \\
(8.63)\end{array}$ & $\begin{array}{l}33.88^{* *} \\
(8.37)\end{array}$ & $\begin{array}{l}32.87^{* *} \\
(8.48)\end{array}$ & $\begin{array}{l}34.71 * * \\
(8.32)\end{array}$ \\
\hline Sr. unsecured & $\begin{array}{l}20.52 * * \\
(4.03)\end{array}$ & $\begin{array}{l}18.20 \text { ** } \\
(4.69)\end{array}$ & $\begin{array}{l}18.21^{* *} \\
(4.53)\end{array}$ & $\begin{array}{l}17.58^{* *} \\
(4.53)\end{array}$ & $\begin{array}{l}19.06^{* *} \\
(4.64)\end{array}$ \\
\hline N. of classes & $\begin{array}{l}-0.66 \\
(1.88)\end{array}$ & $\begin{array}{l}-1.68 \\
(2.86)\end{array}$ & $\begin{array}{l}-1.68 \\
(2.77)\end{array}$ & $\begin{array}{l}-2.21 \\
(2.82)\end{array}$ & $\begin{array}{l}-1.80 \\
(2.90)\end{array}$ \\
\hline Tort & $\begin{array}{l}-4.07 \\
(7.00)\end{array}$ & $\begin{array}{l}-2.18 \\
(8.05)\end{array}$ & $\begin{array}{l}-2.80 \\
(7.81)\end{array}$ & $\begin{array}{l}-9.61 \\
(8.76)\end{array}$ & $\begin{array}{l}-7.48 \\
(8.93)\end{array}$ \\
\hline Energy/utility firms (=1 if yes) & $\begin{array}{c}9.53 \\
(11.72)\end{array}$ & $\begin{array}{c}-6.22 \\
(11.50)\end{array}$ & $\begin{array}{c}-6.62 \\
(11.30)\end{array}$ & $\begin{array}{l}-13.48 \\
(11.57)\end{array}$ & $\begin{array}{c}-9.74 \\
(12.01)\end{array}$ \\
\hline Financial ( $=1$ if yes) & $\begin{array}{l}-2.81 \\
(7.47)\end{array}$ & $\begin{array}{l}-11.83 \\
(11.10)\end{array}$ & $\begin{array}{l}-12.36 \\
(10.45)\end{array}$ & $\begin{array}{c}-16.09 * \\
(9.65)\end{array}$ & $\begin{array}{l}-15.72 \\
(10.35)\end{array}$ \\
\hline Ind. union membership & $\begin{array}{c}0.21 \\
(0.27)\end{array}$ & $\begin{array}{c}0.29 \\
(0.36)\end{array}$ & $\begin{array}{c}0.27 \\
(0.35)\end{array}$ & $\begin{array}{c}0.15 \\
(0.33)\end{array}$ & $\begin{array}{c}0.15 \\
(0.34)\end{array}$ \\
\hline Ind. book leverage & $\begin{array}{l}-0.15 \\
(0.22)\end{array}$ & $\begin{array}{l}-0.33 \\
(0.29)\end{array}$ & $\begin{array}{l}-0.31 \\
(0.29)\end{array}$ & $\begin{array}{l}-0.14 \\
(0.28)\end{array}$ & $\begin{array}{l}-0.19 \\
(0.31)\end{array}$ \\
\hline Ind. return on assets & $\begin{array}{l}-1.32 \\
(2.40)\end{array}$ & $\begin{array}{l}-2.82 \\
(2.76)\end{array}$ & $\begin{array}{l}-2.75 \\
(2.75)\end{array}$ & $\begin{array}{l}-2.84 \\
(2.74)\end{array}$ & $\begin{array}{l}-2.23 \\
(2.83)\end{array}$ \\
\hline Ind. market/book & $\begin{array}{l}-0.02 \\
(0.09)\end{array}$ & $\begin{array}{l}-0.05 \\
(0.11)\end{array}$ & $\begin{array}{l}-0.05 \\
(0.11)\end{array}$ & $\begin{array}{l}-0.04 \\
(0.11)\end{array}$ & $\begin{array}{l}-0.03 \\
(0.12)\end{array}$ \\
\hline Chg. of ind. leverage & $\begin{array}{l}-0.11 \\
(0.34)\end{array}$ & $\begin{array}{c}0.11 \\
(0.44)\end{array}$ & $\begin{array}{c}0.17 \\
(0.48)\end{array}$ & $\begin{array}{c}0.18 \\
(0.48)\end{array}$ & $\begin{array}{c}0.52 \\
(0.51)\end{array}$ \\
\hline Chg. of ind. ROA & $\begin{array}{l}-1.44 \\
(1.62)\end{array}$ & $\begin{array}{l}-0.19 \\
(2.14)\end{array}$ & $\begin{array}{l}-0.24 \\
(2.05)\end{array}$ & $\begin{array}{l}-0.14 \\
(2.09)\end{array}$ & $\begin{array}{l}-0.49 \\
(2.17)\end{array}$ \\
\hline Chg. of ind. mkt/bk & $\begin{array}{c}0.18^{*} \\
(0.10)\end{array}$ & $\begin{array}{l}0.28^{* *} \\
(0.13)\end{array}$ & $\begin{array}{l}0.27^{* *} \\
(0.12)\end{array}$ & $\begin{array}{l}0.30^{* *} \\
(0.13)\end{array}$ & $\begin{array}{l}0.26^{* *} \\
(0.13)\end{array}$ \\
\hline Multiple judges (=1 if yes) & $\begin{array}{c}-19.44 * * \\
(4.27)\end{array}$ & $\begin{array}{c}-14.46^{* *} \\
(5.80)\end{array}$ & $\begin{array}{c}-15.16^{* *} \\
(6.00)\end{array}$ & $\begin{array}{c}-21.54 * * \\
(6.87)\end{array}$ & $\begin{array}{c}-19.76^{* *} \\
(7.54)\end{array}$ \\
\hline Judge tenure & $\begin{array}{c}0.13 \\
(0.31)\end{array}$ & $\begin{array}{c}0.75^{* *} \\
(0.37)\end{array}$ & $\begin{array}{l}0.78^{* *} \\
(0.35)\end{array}$ & $\begin{array}{l}0.96^{* *} \\
(0.37)\end{array}$ & $\begin{array}{l}0.93^{* *} \\
(0.39)\end{array}$ \\
\hline 3-month T-bill & $\begin{array}{l}3.48^{* *} \\
(1.75)\end{array}$ & $\begin{array}{c}4.33 \\
(4.25)\end{array}$ & $\begin{array}{c}4.66 \\
(4.27)\end{array}$ & $\begin{array}{c}6.47 \\
(4.94)\end{array}$ & $\begin{array}{c}7.05 \\
(5.05)\end{array}$ \\
\hline Term premium & $\begin{array}{l}7.07 * * \\
(2.92)\end{array}$ & $\begin{array}{c}4.05 \\
(5.21)\end{array}$ & $\begin{array}{c}4.39 \\
(5.23)\end{array}$ & $\begin{array}{c}6.15 \\
(6.02)\end{array}$ & $\begin{array}{c}6.72 \\
(6.20)\end{array}$ \\
\hline High-yield spreads & $\begin{array}{l}-5.91 * * \\
(1.37)\end{array}$ & $\begin{array}{l}-5.54^{* *} \\
(2.26)\end{array}$ & $\begin{array}{l}-5.26^{* *} \\
(2.30)\end{array}$ & $\begin{array}{l}-3.83 \\
(2.60)\end{array}$ & $\begin{array}{l}-3.31 \\
(2.71)\end{array}$ \\
\hline Chg. of 3-m T-Bill & $\begin{array}{c}3.78^{*} \\
(2.25)\end{array}$ & $\begin{array}{c}2.87 \\
(3.12)\end{array}$ & $\begin{array}{c}3.15 \\
(3.07)\end{array}$ & $\begin{array}{c}4.23 \\
(3.40)\end{array}$ & $\begin{array}{c}4.91 \\
(3.53)\end{array}$ \\
\hline Chg. of term prem & $\begin{array}{l}6.55^{* *} \\
(3.32)\end{array}$ & $\begin{array}{c}2.74 \\
(4.05)\end{array}$ & $\begin{array}{c}2.79 \\
(3.92)\end{array}$ & $\begin{array}{c}1.42 \\
(4.12)\end{array}$ & $\begin{array}{c}2.90 \\
(4.21)\end{array}$ \\
\hline Chg. of HY spreads & $\begin{array}{l}-1.54 \\
(1.11)\end{array}$ & $\begin{array}{l}-1.50 \\
(1.67)\end{array}$ & $\begin{array}{l}-1.57 \\
(1.66)\end{array}$ & $\begin{array}{l}-1.54 \\
(1.59)\end{array}$ & $\begin{array}{l}-1.93 \\
(1.67)\end{array}$ \\
\hline TID & $\begin{array}{l}-0.40^{* *} \\
(0.20)\end{array}$ & $\begin{array}{l}-0.66^{* *} \\
(0.29)\end{array}$ & $\begin{array}{l}-0.53 \\
(0.49)\end{array}$ & $\begin{array}{c}2.24^{*} \\
(1.36)\end{array}$ & \\
\hline $\mathrm{TID}^{2} / 100$ & & & & $\begin{array}{l}-6.05^{* *} \\
(2.56)\end{array}$ & \\
\hline $\log (\mathrm{TID})$ & & & & & $\begin{array}{c}4.26 \\
(9.27)\end{array}$ \\
\hline Correlation parameter & N.A & N.A & $\begin{array}{l}-0.04 \\
(0.13)\end{array}$ & $\begin{array}{l}-0.21 \\
(0.15)\end{array}$ & $\begin{array}{l}-0.21 \\
(0.15)\end{array}$ \\
\hline $\begin{array}{l}\text { Instrumental variables used? } \\
\mathrm{R}^{2} \text { for OLS or log-likelihood for MLE }\end{array}$ & $\begin{array}{l}\text { No } \\
0.31\end{array}$ & $\begin{array}{l}\text { No } \\
0.37\end{array}$ & $\begin{array}{c}\text { Yes } \\
-1732.84 \\
\end{array}$ & $\begin{array}{c}\text { Yes } \\
-1728.80 \\
\end{array}$ & $\begin{array}{c}\text { Yes } \\
-1733.71 \\
\end{array}$ \\
\hline Number of observations (bonds) & 608 & 338 & 338 & 338 & 338 \\
\hline
\end{tabular}




\section{Table 4}

Impact of TID on Bond Recovery Rates Estimated with Firm-Level Financial Variables

This table shows the results on the impact of TID on bond recovery rates using a nonlinear limited information maximum likelihood estimation (NLLIMLE) method. The sample consists of U.S. firms that defaulted on their publicly issued bonds and filed for bankruptcy in 1983-2002. The dependent variable is the bond-level recovery rate and the independent variables include firm-level balance sheet and income statement variables in addition to those used in Table 3. As a result, the number of observations drops significantly. The IVs for TID include real dollar per page fee to obtain court documents and inclement weather, expressed as a fraction of TID.

Note that $*$ and $* *$ indicate that a coefficient is statistically significant at $90 \%$ and $95 \%$ confidence levels, respectively. Standard errors of the coefficients, shown in parentheses, are computed using Huber/White robust method with an assumption that the error terms for the bonds issued by the same firm may be correlated but they are uncorrelated across firms. All specifications include a constant term and dummy variables indicating bond seniority and security, both not shown. 
Table 4 (continued)

Impact of TID on Bond Recovery Rates Estimated with Firm-Level Financial Variables

\begin{tabular}{|c|c|c|c|c|c|}
\hline Independent variables & (1)-OLS & (2)-OLS & (3)-MLE & (4)-MLE & (5)-MLE \\
\hline N. of classes & $\begin{array}{l}-1.68 \\
(2.86)\end{array}$ & $\begin{array}{c}0.02 \\
(3.38)\end{array}$ & $\begin{array}{c}0.11 \\
(3.08)\end{array}$ & $\begin{array}{l}-0.22 \\
(3.17)\end{array}$ & $\begin{array}{c}0.41 \\
(3.22)\end{array}$ \\
\hline Tort & $\begin{array}{l}-2.18 \\
(8.05)\end{array}$ & $\begin{array}{l}-11.11 \\
(17.62)\end{array}$ & $\begin{array}{l}-10.75 \\
(16.84)\end{array}$ & $\begin{array}{l}-12.22 \\
(17.63)\end{array}$ & $\begin{array}{c}-9.69 \\
(17.55)\end{array}$ \\
\hline Energy/utility & $\begin{array}{c}-6.22 \\
(11.50)\end{array}$ & $\begin{array}{c}6.11 \\
(22.60)\end{array}$ & $\begin{array}{c}7.39 \\
(21.18)\end{array}$ & $\begin{array}{c}4.87 \\
(21.76)\end{array}$ & $\begin{array}{c}10.72 \\
(21.54)\end{array}$ \\
\hline Financial & $\begin{array}{l}-11.83 \\
(11.10)\end{array}$ & $\begin{array}{c}-0.07 \\
(15.14)\end{array}$ & $\begin{array}{c}-3.94 \\
(12.74)\end{array}$ & $\begin{array}{c}-8.79 \\
(15.93)\end{array}$ & $\begin{array}{l}-11.24 \\
(17.40)\end{array}$ \\
\hline Ind. union membership & $\begin{array}{c}0.29 \\
(0.36)\end{array}$ & $\begin{array}{c}0.09 \\
(0.49)\end{array}$ & $\begin{array}{c}0.10 \\
(0.45)\end{array}$ & $\begin{array}{c}0.05 \\
(0.43)\end{array}$ & $\begin{array}{c}0.12 \\
(0.44)\end{array}$ \\
\hline Ind. book leverage & $\begin{array}{l}-0.33 \\
(0.29)\end{array}$ & $\begin{array}{c}0.59 \\
(0.42)\end{array}$ & $\begin{array}{c}0.66^{*} \\
(0.39)\end{array}$ & $\begin{array}{c}0.77^{*} \\
(0.44)\end{array}$ & $\begin{array}{c}0.77 \\
(0.49)\end{array}$ \\
\hline Ind. return on assets & $\begin{array}{l}-2.82 \\
(2.76)\end{array}$ & $\begin{array}{c}2.84 \\
(2.75)\end{array}$ & $\begin{array}{c}2.82 \\
(2.53)\end{array}$ & $\begin{array}{c}2.51 \\
(2.61)\end{array}$ & $\begin{array}{c}2.85 \\
(2.54)\end{array}$ \\
\hline Ind. market/book & $\begin{array}{l}-0.05 \\
(0.11)\end{array}$ & $\begin{array}{l}0.24^{* *} \\
(0.11)\end{array}$ & $\begin{array}{l}0.24 * * \\
(0.11)\end{array}$ & $\begin{array}{l}0.23 * * \\
(0.11)\end{array}$ & $\begin{array}{l}0.24 * * \\
(0.11)\end{array}$ \\
\hline Chg. of ind. leverage & $\begin{array}{c}0.11 \\
(0.44)\end{array}$ & $\begin{array}{c}0.50 \\
(0.72)\end{array}$ & $\begin{array}{c}0.66 \\
(0.70)\end{array}$ & $\begin{array}{c}0.78 \\
(0.74)\end{array}$ & $\begin{array}{c}0.96 \\
(0.85)\end{array}$ \\
\hline Chg. of ind. ROA & $\begin{array}{l}-0.19 \\
(2.14)\end{array}$ & $\begin{array}{c}4.29 \\
(4.21)\end{array}$ & $\begin{array}{c}3.63 \\
(3.63)\end{array}$ & $\begin{array}{c}2.67 \\
(3.99)\end{array}$ & $\begin{array}{c}2.47 \\
(4.46)\end{array}$ \\
\hline Chg. of ind. mkt/bk & $\begin{array}{l}0.28^{* *} \\
(0.13)\end{array}$ & $\begin{array}{c}0.32 * \\
(0.16)\end{array}$ & $\begin{array}{l}0.32 * * \\
(0.15)\end{array}$ & $\begin{array}{l}0.34^{* *} \\
(0.16)\end{array}$ & $\begin{array}{l}0.32 * * \\
(0.16)\end{array}$ \\
\hline Multiple judges (=1 if yes) & $\begin{array}{c}-14.46^{* *} \\
(5.80)\end{array}$ & $\begin{array}{l}-7.55 \\
(8.47)\end{array}$ & $\begin{array}{l}-6.87 \\
(8.08)\end{array}$ & $\begin{array}{l}-7.26 \\
(8.24)\end{array}$ & $\begin{array}{l}-5.48 \\
(8.51)\end{array}$ \\
\hline Judge tenure & $\begin{array}{l}0.75 * * \\
(0.37)\end{array}$ & $\begin{array}{c}0.37 \\
(0.43)\end{array}$ & $\begin{array}{c}0.45 \\
(0.42)\end{array}$ & $\begin{array}{c}0.61 \\
(0.60)\end{array}$ & $\begin{array}{c}0.56 \\
(0.63)\end{array}$ \\
\hline 3-month T-bill & $\begin{array}{c}4.33 \\
(4.25)\end{array}$ & $\begin{array}{c}5.55 \\
(7.48)\end{array}$ & $\begin{array}{l}7.09 \\
(7.64)\end{array}$ & $\begin{array}{c}9.23 \\
(9.16)\end{array}$ & $\begin{array}{c}9.81 \\
(9.42)\end{array}$ \\
\hline Term premium & $\begin{array}{c}4.05 \\
(5.21)\end{array}$ & $\begin{array}{c}0.99 \\
(9.60)\end{array}$ & $\begin{array}{c}2.89 \\
(9.88)\end{array}$ & $\begin{array}{c}5.43 \\
(11.73)\end{array}$ & $\begin{array}{c}6.17 \\
(12.05)\end{array}$ \\
\hline High-yield spreads & $\begin{array}{l}-5.54^{* *} \\
(2.26)\end{array}$ & $\begin{array}{l}-1.42 \\
(3.44)\end{array}$ & $\begin{array}{l}-0.55 \\
(3.45)\end{array}$ & $\begin{array}{c}0.51 \\
(4.22)\end{array}$ & $\begin{array}{c}1.06 \\
(4.75)\end{array}$ \\
\hline Chg. of 3-m T-Bill & $\begin{array}{c}2.87 \\
(3.12)\end{array}$ & $\begin{array}{l}-1.62 \\
(3.98)\end{array}$ & $\begin{array}{l}-0.32 \\
(3.92)\end{array}$ & $\begin{array}{c}1.17 \\
(5.15)\end{array}$ & $\begin{array}{c}1.95 \\
(5.96)\end{array}$ \\
\hline Chg. of term prem & $\begin{array}{c}2.74 \\
(4.05)\end{array}$ & $\begin{array}{l}-3.41 \\
(5.29)\end{array}$ & $\begin{array}{l}-2.29 \\
(4.69)\end{array}$ & $\begin{array}{l}-1.58 \\
(4.84)\end{array}$ & $\begin{array}{l}-0.26 \\
(5.44)\end{array}$ \\
\hline Chg. of HY spreads & $\begin{array}{l}-1.50 \\
(1.67)\end{array}$ & $\begin{array}{l}-4.63 * * \\
(1.87)\end{array}$ & $\begin{array}{l}-4.48^{* *} \\
(1.74)\end{array}$ & $\begin{array}{l}-4.24 * * \\
(1.91)\end{array}$ & $\begin{array}{l}-4.20 * * \\
(1.89)\end{array}$ \\
\hline Time in default & $\begin{array}{l}-0.66^{* *} \\
(0.29)\end{array}$ & $\begin{array}{l}-0.84^{*} \\
(0.43)\end{array}$ & $\begin{array}{l}-0.59 \\
(0.62)\end{array}$ & $\begin{array}{c}0.43 \\
(2.14)\end{array}$ & \\
\hline Time in default ${ }^{2} / 100$ & & & & $\begin{array}{l}-1.89 \\
(3.64)\end{array}$ & \\
\hline Log(Time in default) & & & & & $\begin{array}{c}-2.01 \\
(15.68)\end{array}$ \\
\hline $\log$ (assets) & & $\begin{array}{l}-0.62 \\
(3.16)\end{array}$ & $\begin{array}{l}-0.41 \\
(2.91)\end{array}$ & $\begin{array}{l}-0.11 \\
(3.12)\end{array}$ & $\begin{array}{l}-0.09 \\
(3.32)\end{array}$ \\
\hline Book leverage & & $\begin{array}{l}-0.09 \\
(0.08)\end{array}$ & $\begin{array}{l}-0.08 \\
(0.08)\end{array}$ & $\begin{array}{l}-0.07 \\
(0.08)\end{array}$ & $\begin{array}{l}-0.07 \\
(0.08)\end{array}$ \\
\hline Return on assets & & $\begin{array}{c}0.31 \\
(0.49)\end{array}$ & $\begin{array}{c}0.35 \\
(0.46)\end{array}$ & $\begin{array}{c}0.31 \\
(0.47)\end{array}$ & $\begin{array}{c}0.45 \\
(0.48)\end{array}$ \\
\hline Tangible/total assets & & $\begin{array}{l}-0.12 \\
(0.20)\end{array}$ & $\begin{array}{l}-0.13 \\
(0.19)\end{array}$ & $\begin{array}{l}-0.11 \\
(0.19)\end{array}$ & $\begin{array}{l}-0.16 \\
(0.19)\end{array}$ \\
\hline Correlation parameter & N.A & N.A & $\begin{array}{l}-0.07 \\
(0.17)\end{array}$ & $\begin{array}{l}-0.14 \\
(0.23)\end{array}$ & $\begin{array}{l}-0.15 \\
(0.23)\end{array}$ \\
\hline Seniority and security dummies significant? & Yes & Yes & Yes & Yes & Yes \\
\hline Instrumental variables used? & No & No & Yes & Yes & Yes \\
\hline $\mathrm{R}^{2}$ for OLS or log-likelihood for MLE & 0.37 & 0.48 & -889.19 & -889.02 & -889.72 \\
\hline Number of observations (bonds) & 338 & 184 & 184 & 184 & 184 \\
\hline
\end{tabular}




\section{Table 5}

\section{Impact of TID on Firm-Aggregate Bond Recovery Rates}

This table shows the results on the impact of TID on bond recovery rates using a nonlinear limited information maximum likelihood estimation (NLLIMLE) method. The sample consists of U.S. firms that defaulted on their publicly issued bonds and filed for bankruptcy in 1983-2002. The dependent variable is the firm-level recovery rate, equal to average bond recovery rate weighted by bond outstanding. In the specifications (1)-(4), the independent variables include industry, macroeconomic, and bankruptcy complexity variables and TID. Firm-level balance sheet and income statement variables, not shown, are added to the equation in specification (5), resulting a smaller sample size. The IVs for TID include real dollar per page fee to obtain court documents and inclement weather, expressed as a fraction of TID.

Note that $*$ and $* *$ indicate that a coefficient is statistically significant at $90 \%$ and $95 \%$ confidence levels, respectively. Standard errors of the coefficients, shown in parentheses, are computed using Huber/White robust method. All specifications include a constant term, not shown. 
Table 5 (continued)

Impact of TID on Firm-Aggregate Bond Recovery Rates

\begin{tabular}{|c|c|c|c|c|c|}
\hline Independent variables & $\begin{array}{c}(1) \\
\text { OLS }\end{array}$ & $\begin{array}{c}\text { (2) } \\
\text { MLE }\end{array}$ & $\begin{array}{c}\text { (3) } \\
\text { MLE }\end{array}$ & $\begin{array}{c}\text { (4) } \\
\text { MLE }\end{array}$ & $\begin{array}{c}\text { (5) } \\
\text { MLE }\end{array}$ \\
\hline N. of classes & $\begin{array}{c}3.53^{*} \\
(1.88)\end{array}$ & $\begin{array}{c}3.49^{*} \\
(1.78)\end{array}$ & $\begin{array}{c}3.05 \\
(1.94)\end{array}$ & $\begin{array}{c}3.12 \\
(2.02)\end{array}$ & $\begin{array}{c}0.59 \\
(2.90)\end{array}$ \\
\hline Tort & $\begin{array}{l}-1.04 \\
(5.24)\end{array}$ & $\begin{array}{l}-3.71 \\
(5.40)\end{array}$ & $\begin{array}{l}-7.36 \\
(6.54)\end{array}$ & $\begin{array}{r}-10.45 \\
(7.42)\end{array}$ & $\begin{array}{l}-41.24 * * \\
(11.47)\end{array}$ \\
\hline Energy/utility & $\begin{array}{l}-9.72 * \\
(5.62)\end{array}$ & $\begin{array}{c}-11.99 * * \\
(5.84)\end{array}$ & $\begin{array}{c}-15.42^{* *} \\
(6.66)\end{array}$ & $\begin{array}{c}-18.16^{* * *} \\
(7.74)\end{array}$ & $\begin{array}{l}-16.21 \\
(15.17)\end{array}$ \\
\hline Financial & $\begin{array}{l}-6.06 \\
(9.76)\end{array}$ & $\begin{array}{l}-7.22 \\
(9.34)\end{array}$ & $\begin{array}{r}-10.42 \\
(9.76)\end{array}$ & $\begin{array}{l}-10.74 \\
(10.64)\end{array}$ & $\begin{array}{l}-36.03^{*} \\
(21.35)\end{array}$ \\
\hline Ind. union membership & $\begin{array}{c}0.20 \\
(0.20)\end{array}$ & $\begin{array}{c}0.11 \\
(0.19)\end{array}$ & $\begin{array}{c}0.00 \\
(0.22)\end{array}$ & $\begin{array}{l}-0.08 \\
(0.25)\end{array}$ & $\begin{array}{l}-0.27 \\
(0.44)\end{array}$ \\
\hline Multiple/switching judge & $\begin{array}{l}-7.28 \\
(6.18)\end{array}$ & $\begin{array}{l}-9.09 \\
(6.04)\end{array}$ & $\begin{array}{c}-14.06^{* *} \\
(7.10)\end{array}$ & $\begin{array}{r}-15.00 * \\
(7.67)\end{array}$ & $\begin{array}{c}3.66 \\
(10.59)\end{array}$ \\
\hline Judge tenure & $\begin{array}{c}0.16 \\
(0.27)\end{array}$ & $\begin{array}{c}0.18 \\
(0.26)\end{array}$ & $\begin{array}{c}0.21 \\
(0.28)\end{array}$ & $\begin{array}{c}0.23 \\
(0.31)\end{array}$ & $\begin{array}{l}1.39 * * \\
(0.46)\end{array}$ \\
\hline Ind. book leverage & $\begin{array}{c}0.07 \\
(0.22)\end{array}$ & $\begin{array}{c}0.11 \\
(0.22)\end{array}$ & $\begin{array}{c}0.22 \\
(0.22)\end{array}$ & $\begin{array}{c}0.24 \\
(0.25)\end{array}$ & $\begin{array}{l}1.01^{* *} \\
(0.46)\end{array}$ \\
\hline Chg. of ind. leverage & $\begin{array}{l}-0.45 \\
(0.43)\end{array}$ & $\begin{array}{l}-0.20 \\
(0.46)\end{array}$ & $\begin{array}{c}0.03 \\
(0.48)\end{array}$ & $\begin{array}{c}0.33 \\
(0.57)\end{array}$ & $\begin{array}{c}0.99 \\
(0.99)\end{array}$ \\
\hline Ind. return on assets & $\begin{array}{c}1.29 \\
(1.95)\end{array}$ & $\begin{array}{c}1.69 \\
(2.03)\end{array}$ & $\begin{array}{c}1.85 \\
(2.33)\end{array}$ & $\begin{array}{c}2.37 \\
(2.51)\end{array}$ & $\begin{array}{c}3.29 \\
(3.13)\end{array}$ \\
\hline Chg. of ind. ROA & $\begin{array}{c}2.42 \\
(2.16)\end{array}$ & $\begin{array}{c}2.27 \\
(2.11)\end{array}$ & $\begin{array}{c}2.15 \\
(2.29)\end{array}$ & $\begin{array}{c}1.88 \\
(2.58)\end{array}$ & $\begin{array}{c}2.17 \\
(4.70)\end{array}$ \\
\hline Ind. market/book & $\begin{array}{c}0.10 \\
(0.09)\end{array}$ & $\begin{array}{c}0.13 \\
(0.09)\end{array}$ & $\begin{array}{c}0.16 \\
(0.10)\end{array}$ & $\begin{array}{c}0.19^{*} \\
(0.11)\end{array}$ & $\begin{array}{l}0.41^{* *} \\
(0.13)\end{array}$ \\
\hline Chg. of ind. mkt/bk & $\begin{array}{l}0.25^{* *} \\
(0.10)\end{array}$ & $\begin{array}{l}0.25^{* *} \\
(0.10)\end{array}$ & $\begin{array}{l}0.26^{* *} \\
(0.10)\end{array}$ & $\begin{array}{l}0.26^{* *} \\
(0.10)\end{array}$ & $\begin{array}{l}0.35^{* *} \\
(0.13)\end{array}$ \\
\hline 3-month T-bill & $\begin{array}{c}3.61 \\
(3.62)\end{array}$ & $\begin{array}{c}4.85 \\
(3.63)\end{array}$ & $\begin{array}{c}7.51^{*} \\
(4.38)\end{array}$ & $\begin{array}{r}8.81^{*} \\
(5.28)\end{array}$ & $\begin{array}{l}12.58^{* * *} \\
(6.24)\end{array}$ \\
\hline Term premium & $\begin{array}{r}7.47^{*} \\
(4.46)\end{array}$ & $\begin{array}{l}8.71 * * \\
(4.42)\end{array}$ & $\begin{array}{l}11.59^{* *} \\
(5.28)\end{array}$ & $\begin{array}{l}12.92 * * \\
(6.40)\end{array}$ & $\begin{array}{l}14.86^{*} \\
(7.92)\end{array}$ \\
\hline Chg. of 3-m T-Bill & $\begin{array}{c}4.34 \\
(2.66)\end{array}$ & $\begin{array}{l}5.77 * * \\
(2.72)\end{array}$ & $\begin{array}{l}6.79 * * \\
(3.12)\end{array}$ & $\begin{array}{l}8.97 * * \\
(3.71)\end{array}$ & $\begin{array}{l}8.02 * * \\
(4.04)\end{array}$ \\
\hline Chg. of term prem & $\begin{array}{c}4.45 \\
(3.68)\end{array}$ & $\begin{array}{c}4.89 \\
(3.51)\end{array}$ & $\begin{array}{c}4.45 \\
(3.82)\end{array}$ & $\begin{array}{c}5.55 \\
(4.12)\end{array}$ & $\begin{array}{l}-0.70 \\
(5.23)\end{array}$ \\
\hline High-yield spreads & $\begin{array}{l}-3.07 * \\
(1.77)\end{array}$ & $\begin{array}{l}-1.93 \\
(1.90)\end{array}$ & $\begin{array}{l}-0.63 \\
(2.23)\end{array}$ & $\begin{array}{c}0.82 \\
(2.72)\end{array}$ & $\begin{array}{c}6.04 * \\
(3.22)\end{array}$ \\
\hline Chg. of HY spreads & $\begin{array}{l}-0.38 \\
(1.38)\end{array}$ & $\begin{array}{l}-0.69 \\
(1.36)\end{array}$ & $\begin{array}{l}-1.43 \\
(1.51)\end{array}$ & $\begin{array}{l}-1.56 \\
(1.62)\end{array}$ & $\begin{array}{l}-0.74 \\
(2.44)\end{array}$ \\
\hline TID & $\begin{array}{l}-0.47 * * \\
(0.23)\end{array}$ & $\begin{array}{l}-0.00 \\
(0.43)\end{array}$ & $\begin{array}{l}2.77 * * \\
(1.41)\end{array}$ & & $\begin{array}{l}4.30^{*} \\
(2.35)\end{array}$ \\
\hline $\mathrm{TID}^{2} / 100$ & & & $\begin{array}{l}-5.18^{* *} \\
(2.21)\end{array}$ & & $\begin{array}{l}-8.43 * * \\
(3.89)\end{array}$ \\
\hline $\log (\mathrm{TID})$ & & & & $\begin{array}{c}18.85 \\
(13.69) \\
\end{array}$ & \\
\hline Correlation parameter & $\mathrm{N} / \mathrm{A}$ & $\begin{array}{l}-0.18 \\
(0.14)\end{array}$ & $\begin{array}{c}-0.43 * * \\
(0.17)\end{array}$ & $\begin{array}{c}-0.50 * * \\
(0.20)\end{array}$ & $\begin{array}{c}-0.44^{*} \\
(0.23)\end{array}$ \\
\hline Firm financial variable included? & No & No & No & No & Yes \\
\hline Instrumental variables used? & No & Yes & Yes & Yes & Yes \\
\hline $\begin{array}{l}\mathrm{R}^{2} \text { for OLS or log-likelihood for MLE } \\
\text { Number of observations (firms) }\end{array}$ & $\begin{array}{r}0.31 \\
169\end{array}$ & $\begin{array}{c}-852.0 \\
169\end{array}$ & $\begin{array}{c}-848.9 \\
169\end{array}$ & $\begin{array}{c}-849.8 \\
169\end{array}$ & $\begin{array}{r}-422.1 \\
86\end{array}$ \\
\hline
\end{tabular}


Table 6

Impact of TID on Bond Recovery Rate with Interactive Terms

This table shows the results on the impact of TID on bond recovery rates using a nonlinear limited information maximum likelihood estimation (NLLIMLE) method. The sample consists of U.S. firms that defaulted on their publicly issued bonds and filed for bankruptcy in 1983-2002. The dependent variable is the bond-level recovery rate and the independent variables include contract, industry, macroeconomic, and bankruptcy complexity variables, TID, and interactive terms between TID and an indicator variable. The IVs for TID include real dollar per page fee to obtain court documents and inclement weather, expressed as a fraction of TID.

Note that $*$ and $* *$ indicate that a coefficient is statistically significant at $90 \%$ and $95 \%$ confidence levels, respectively. Standard errors of the coefficients, shown in parentheses, are computed using Huber/White robust method with an assumption that the error terms for the bonds issued by the same firm may be correlated but they are uncorrelated across firms. To save space, only the coefficients of variables derived from TID are shown. The coefficients and their standard errors are shown in bold if TID and its squared term (with or without interactive variables) are jointly statistically significant at the $90 \%$ or $95 \%$ confidence level. 
Table 6 (continued).

Impact of TID on Bond Recovery Rate with Interactive Terms

\begin{tabular}{|c|c|c|c|c|c|c|}
\hline Independent variables & $\begin{array}{c}(1) \\
\text { Financial }\end{array}$ & $\begin{array}{c}(2) \\
\text { N. of classes }\end{array}$ & $\begin{array}{l}(3) \\
\text { Tort }\end{array}$ & $\begin{array}{c}(4) \\
\text { Recession }\end{array}$ & $\begin{array}{c}5) \\
\text { Union }\end{array}$ & $\begin{array}{c}(6) \\
\text { Firm size }\end{array}$ \\
\hline TID & $\begin{array}{c}1.95 \\
(1.37)\end{array}$ & $\begin{array}{c}3.02 \\
(2.83)\end{array}$ & $\begin{array}{l}2.49 * \\
(1.35)\end{array}$ & $\begin{array}{c}1.98 \\
(1.38)\end{array}$ & $\begin{array}{c}1.54 \\
(1.42)\end{array}$ & $\begin{array}{l}2.98 * * \\
(1.34)\end{array}$ \\
\hline $\mathrm{TID}^{2} / 100$ & $\begin{array}{l}-5.48 * * \\
(2.58)\end{array}$ & $\begin{array}{l}-10.17 \\
(10.84)\end{array}$ & $\begin{array}{l}-6.62^{* *} \\
(2.54)\end{array}$ & $\begin{array}{l}-5.51 * * \\
(2.55)\end{array}$ & $\begin{array}{l}-3.72 \\
(3.14)\end{array}$ & $\begin{array}{l}-7.15^{* *} \\
(2.46)\end{array}$ \\
\hline TID*Financial & $\begin{array}{c}7.13 \\
(4.94)\end{array}$ & & & & & \\
\hline $\mathrm{TID}^{2} / 100 *$ Financial & $\begin{array}{l}-20.35 \\
(16.34)\end{array}$ & & & & & \\
\hline TID*(N. of classes $>1)$ & & $\begin{array}{l}-0.65 \\
(2.26)\end{array}$ & & & & \\
\hline $\mathrm{TID}^{2} / 100 *(\mathrm{~N}$. of classes $>1)$ & & $\begin{array}{c}3.95 \\
(10.01)\end{array}$ & & & & \\
\hline TID*Tort & & & $\begin{array}{l}-6.58 \\
(4.82)\end{array}$ & & & \\
\hline $\mathrm{TID}^{2} / 100 *$ Tort & & & $\begin{array}{c}15.46 \\
(13.72)\end{array}$ & & & \\
\hline TID*Recession & & & & $\begin{array}{c}0.76 \\
(1.00)\end{array}$ & & \\
\hline $\mathrm{TID}^{2} / 100 *$ Recession & & & & $\begin{array}{c}0.01 \\
(3.46)\end{array}$ & & \\
\hline TID*(Union, $1^{\text {st }}$ qtile) & & & & & $\begin{array}{c}0.54 \\
(1.05)\end{array}$ & \\
\hline $\mathrm{TID}^{2} / 100^{*}$ (Union, $1^{\text {st }}$ qtile $)$ & & & & & $\begin{array}{l}-2.99 \\
(3.19)\end{array}$ & \\
\hline TID*(Union, $4^{\text {th }}$ qtile) & & & & & $\begin{array}{l}2.49 * * \\
(1.23)\end{array}$ & \\
\hline $\mathrm{TID}^{2} / 100 *\left(\right.$ Union, $4^{\text {th }}$ qtile $)$ & & & & & $\begin{array}{l}-4.71 \\
(3.91)\end{array}$ & \\
\hline TID*(All debt, $1^{\text {st }}$ qtile $)$ & & & & & & $\begin{array}{l}-0.58 \\
(0.81)\end{array}$ \\
\hline $\mathrm{TID}^{2} / 100^{*}\left(\right.$ All debt, $1^{\text {st }}$ qtile $)$ & & & & & & $\begin{array}{l}-1.04 \\
(2.76)\end{array}$ \\
\hline TID*(All debt, $4^{\text {th }}$ qtile $)$ & & & & & & $\begin{array}{l}-0.53 \\
(1.34)\end{array}$ \\
\hline $\mathrm{TID}^{2} / 100^{*}\left(\right.$ All debt, $4^{\text {th }}$ qtile $)$ & & & & & & $\begin{array}{c}1.90 \\
(4.04)\end{array}$ \\
\hline Correlation parameter & $\begin{array}{l}-0.22 \\
(0.14)\end{array}$ & $-0.021(0.15)$ & $\begin{array}{l}-0.19 \\
(0.15)\end{array}$ & $\begin{array}{l}-0.24 \\
(0.15)\end{array}$ & $\begin{array}{l}-0.20 \\
(0.14)\end{array}$ & $\begin{array}{l}-0.25^{*} \\
(0.14)\end{array}$ \\
\hline Instrument variables used? & Yes & Yes & Yes & Yes & Yes & Yes \\
\hline Log-likelihood & -1726.6 & -1728.6 & -1727.2 & -1725.6 & -1723.2 & -1725.3 \\
\hline Number of observations (bonds) & 338 & 338 & 338 & 338 & 338 & 338 \\
\hline
\end{tabular}




\section{Table 7}

\section{Impact of TID on the Likelihood of Refiling within Five Years of Emerging from A Bankruptcy}

This table shows the results on the impact of TID on the likelihood of a firm reentering bankruptcy within five years after it emerges from a bankruptcy using a nonlinear limited information maximum likelihood estimation (NLLIMLE) method. The sample consists of U.S. firms that defaulted on their publicly issued bonds and filed for bankruptcy in 1983-2002. The dependent variable is an indicator, equal to 1 if a firm refilled and 0 otherwise. The independent variables for the latent equation that determines refiling decisions include industry, macroeconomic, and bankruptcy complexity variables and TID. The IVs for TID include real dollar per page fee to obtain court documents and inclement weather, expressed as a fraction of TID.

Note that $*$ and $* *$ indicate that a coefficient is statistically significant at $90 \%$ and $95 \%$ confidence levels, respectively. Standard errors of the coefficients, calculated using the Huber/White robust method, are shown in parentheses. All specifications include a constant term, not shown. 
Table 7 (continued)

Impact of TID on the Likelihood of Refiling within Five Years of Emerging from A Bankruptcy

\begin{tabular}{|c|c|c|c|c|}
\hline \multicolumn{5}{|c|}{ Dependent variable: 1 if refiled, 0 otherwise } \\
\hline Independent variables & (1)-Probit & (2)-MLE & (3)-MLE & (4)-MLE \\
\hline \multirow[t]{2}{*}{ Tort } & -0.53 & -0.32 & -0.09 & -0.39 \\
\hline & $(0.60)$ & $(0.62)$ & $(0.59)$ & $(0.63)$ \\
\hline \multirow[t]{2}{*}{ Number of classes } & $0.35^{*}$ & $0.35 *$ & $0.37 * *$ & $0.36^{*}$ \\
\hline & $(0.20)$ & $(0.19)$ & $(0.18)$ & $(0.19)$ \\
\hline \multirow[t]{2}{*}{ Energy/utility } & $1.25 *$ & $1.48 * *$ & $1.32 * *$ & $1.30^{* *}$ \\
\hline & $(0.65)$ & $(0.66)$ & $(0.59)$ & $(0.62)$ \\
\hline \multirow[t]{2}{*}{ Industry union membership } & 0.02 & 0.02 & 0.02 & 0.02 \\
\hline & $(0.02)$ & $(0.02)$ & $(0.02)$ & $(0.02)$ \\
\hline \multirow{2}{*}{ Multiple/switching judges ( 1 if yes) } & $1.89 * *$ & $1.97 * *$ & $1.89 * *$ & $1.93 * *$ \\
\hline & $(0.65)$ & $(0.64)$ & $(0.60)$ & $(0.63)$ \\
\hline \multirow[t]{2}{*}{ Industry book leverage } & 0.00 & 0.00 & 0.00 & 0.00 \\
\hline & $(0.02)$ & $(0.02)$ & $(0.02)$ & $(0.02)$ \\
\hline \multirow[t]{2}{*}{ Chg. of ind. book leverage } & 0.06 & 0.04 & 0.04 & 0.05 \\
\hline & $(0.05)$ & $(0.05)$ & $(0.05)$ & $(0.05)$ \\
\hline \multirow[t]{2}{*}{ Industry return on assets } & 0.28 & 0.26 & 0.17 & 0.26 \\
\hline & $(0.18)$ & $(0.19)$ & $(0.18)$ & $(0.19)$ \\
\hline \multirow[t]{2}{*}{ Chg. of ind. return on assets } & -0.07 & -0.10 & -0.08 & -0.06 \\
\hline & $(0.20)$ & $(0.20)$ & $(0.19)$ & $(0.20)$ \\
\hline \multirow[t]{2}{*}{ Industry market/book ratio } & 0.00 & 0.00 & 0.00 & 0.00 \\
\hline & $(0.01)$ & $(0.01)$ & $(0.01)$ & $(0.01)$ \\
\hline \multirow{2}{*}{ Chg. of ind. market/book ratio } & 0.00 & 0.00 & -0.00 & 0.00 \\
\hline & $(0.01)$ & $(0.01)$ & $(0.01)$ & $(0.01)$ \\
\hline \multirow[t]{2}{*}{ 3-month T-bill rate } & $-1.46^{* *}$ & $-1.58 * *$ & $-1.45^{* *}$ & $-1.54 * *$ \\
\hline & $(0.56)$ & $(0.55)$ & $(0.50)$ & $(0.55)$ \\
\hline \multirow{2}{*}{ Term premium } & $-1.07 * *$ & $-1.13 * *$ & $-1.09 * *$ & $-1.13^{* *}$ \\
\hline & $(0.53)$ & $(0.53)$ & $(0.48)$ & $(0.52)$ \\
\hline \multirow[t]{2}{*}{ Chg. of 3-month T-bill rate } & -0.17 & -0.29 & -0.33 & -0.25 \\
\hline & $(0.26)$ & $(0.29)$ & $(0.26)$ & $(0.28)$ \\
\hline \multirow[t]{2}{*}{ Chg. of term premium } & 0.18 & 0.17 & 0.06 & 0.14 \\
\hline & $(0.39)$ & $(0.39)$ & $(0.36)$ & $(0.38)$ \\
\hline \multirow[t]{2}{*}{ High-yield spread } & $-0.69 * *$ & $-0.80 * *$ & $-0.76^{* *}$ & $-0.76^{* *}$ \\
\hline & $(0.26)$ & $(0.27)$ & $(0.23)$ & $(0.27)$ \\
\hline \multirow[t]{2}{*}{ Chg. of high-yield spread } & -0.09 & -0.07 & -0.09 & -0.09 \\
\hline & $(0.13)$ & $(0.13)$ & $(0.13)$ & $(0.13)$ \\
\hline \multirow[t]{2}{*}{ TID } & -0.02 & -0.06 & $-0.22 * *$ & \\
\hline & $(0.03)$ & $(0.05)$ & $(0.09)$ & \\
\hline \multirow[t]{2}{*}{$\mathrm{TID}^{2} / 100$} & & & $0.34 *$ & \\
\hline & & & $(0.19)$ & \\
\hline \multirow[t]{2}{*}{$\log (\mathrm{TID})$} & & & & -0.78 \\
\hline & & & & $(0.76)$ \\
\hline \multirow[t]{2}{*}{ Constant } & $7.37 *$ & $9.42 * *$ & $10.52 * *$ & $9.96^{*}$ \\
\hline & $(4.24)$ & $(4.56)$ & $(3.93)$ & $(5.16)$ \\
\hline Correlation parameter & N.A & 0.26 & $0.55 * *$ & 0.27 \\
\hline & & $(0.28)$ & $(0.26)$ & $(0.33)$ \\
\hline Log-likelihood & -34.07 & -173.15 & -171.95 & -173.46 \\
\hline Instrumental variables & No & Yes & Yes & Yes \\
\hline Number of observations & 245 & 245 & 245 & 245 \\
\hline
\end{tabular}




\section{Appendix \\ Defining Disruptive Events}

Information regarding weather events comes from the Storm Events Database of the National Climatic Data Center (NCDC) of the National Oceanic and Atmospheric Administration (NOAA). The data are classified by county, date, and climatic event. All counties relevant for our courts are included. The climatic events included in the database are as follows: Drought, Dust Storm \& Dust Devil, Flood, Fog, Funnel Cloud \& Waterspout, Hail, Hurricane \& Tropical Storm, Lightning, Ocean \& Lake Surf, Precipitation, Snow \& Ice, Blizzard, Temperature Extremes, Thunderstorm \& High Wind, Tornado, and Wild \& Forest Fire. We have selected Snow and Ice, Blizzard, Floods, Hurricanes, and Wild and Forest Fires. For these categories, climatic data are for January 1, 1993 through the present, with a 90-120 day lag. Data are updated monthly. We searched from January 1, 1993 through December 31, 2003.

We searched for major climatic events for 13 courts: Delaware, Southern District of New York, Arizona, Northern District of Texas, Southern District of Texas, Maryland, Eastern District of Wisconsin, Northern District of California, Central District of California, Eastern District of North Carolina, Massachusetts, Southern District of Ohio, and Northern District of Illinois. ${ }^{15}$ The venues were selected to maximize the number of observations and cover more than 90 percent of defaulted bonds in the sample.

To determine whether a climatic event was likely to be disruptive to the bankruptcy court, we selected the more extreme events and reviewed the descriptions provided by the NCDC. The following summarizes the criteria used.

\section{Winter weather:}

Any blizzard event is included regardless of the description (blizzards require a specific search). There were other snow and ice events which warranted inclusion. These events are designated as being "Winter Storm" or "Heavy Snow". Generally speaking, the description needs to contain something referring to "record snowfall", "schools closed", "major roads closed", "airports closed", or "whiteout conditions" to be considered relevant. In Texas courts, a number of ice storms are considered worthy.

\section{Floods:}

Floods or storm surges are considered important if the description pointed out that the county of the bankruptcy court was declared a federal and/or state disaster area or if the description mentioned large-scale evacuations.

\section{Hurricanes and tropical storms:}

Both tropical storms occurring in the Southern District of Texas (Dallas) during the period are included. T.S. Frances (September 7-12, 1998) caused "significant flooding" and T.S. Allison (June 5-10, 2001) caused a 12-hour shutdown of downtown Houston.

\footnotetext{
${ }^{15}$ In cases where bankruptcy courts had divisions in more than one county, searches were either performed on climatic events in each county, or the search was limited to the division of the judge assigned to the cases.
} 
Wild/forest fires:

Although outside the time period covered by the NOAA database, we included the Oakland fire of 1991.

Earthquakes and other events:

Seismic events which made the cutoff were the Loma Prieta earthquake affecting the San Francisco Bay Area in 1989 and the 1994 Northridge quake affecting the Southern California. We also included the 1992 Los Angeles Riots over the dates newspapers specifically mentioned that courts were closed. 